\title{
Oxygen and carbon isotope composition of modern planktic foraminifera and near-surface waters in the Fram Strait (Arctic Ocean) - a case study
}

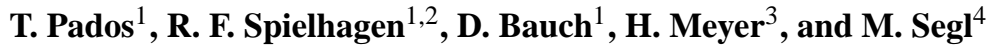 \\ ${ }^{1}$ GEOMAR Helmholtz Centre for Ocean Research Kiel, Kiel, Germany \\ ${ }^{2}$ Academy of Sciences, Humanities, and Literature Mainz, Mainz, Germany \\ ${ }^{3}$ Alfred Wegener Institute Helmholtz Centre for Polar and Marine Research, Potsdam, Germany \\ ${ }^{4}$ MARUM - Center for Marine Environmental Sciences, Bremen, Germany
}

Correspondence to: T. Pados (tpados@geomar.de)

Received: 14 May 2014 - Published in Biogeosciences Discuss.: 11 June 2014

Revised: 16 January 2015 - Accepted: 20 January 2015 - Published: 17 March 2015

\begin{abstract}
The upper $500 \mathrm{~m}$ of the water column and the sediment surface along an E-W transect in the Fram Strait were sampled for recent planktic foraminifera. The $\delta^{18} \mathrm{O}$ and $\delta^{13} \mathrm{C}$ values of the tests are compared to the stable isotope composition of the water samples taken from the same depths, and related to the characteristics of the water column. The polar species Neogloboquadrina pachyderma clearly dominates the species assemblage in the Fram Strait in the early summer, while the subpolar Turborotalita quinqueloba accounts only for 5-23\%. In this area the average depth of calcification of $N$. pachyderma lies between 70-150 m water depth, T. quinqueloba shows a similar range with 50-120 m water depth. The $\delta^{18} \mathrm{O}$ values of $N$. pachyderma show an average vital effect of about $-1.5 \%$ compared to calculated equilibrium calcite values. Except for the upper $\sim 75 \mathrm{~m}$, the vertical profiles of $\delta^{13} \mathrm{C}$ of the net-sampled shells are nearly parallel to the values measured in the water column with an average offset of $-1.6 \%$ and $-3.6 \%$ for $N$. pachyderma and T. quinqueloba, respectively. The discrepancy found in the upper $\sim 75 \mathrm{~m}$ might indicate an influence of the "carbonate ion effect" on the carbon isotope incorporation in the tests. Oxygen and carbon isotopes from the sediment surface yield higher values than those from the water column for both species. This may be because specimens from the water column reflect a modern snapshot only, while tests from surface sediments record environmental parameters from the past $\sim 1000$ years.
\end{abstract}

\section{Introduction}

The stable isotope composition of foraminiferal shells from sediment cores is often used in palaeoceanographic studies to reconstruct past oceanic environments. Planktic foraminifera precipitate their calcite tests from the surrounding seawater. Thus, the stable oxygen isotope ratios $\left({ }^{18} \mathrm{O} /{ }^{16} \mathrm{O}, \delta^{18} \mathrm{O}\right)$ of shell carbonate are controlled by the ratio in the seawater and the calcification temperature, while the stable carbon isotope ratios $\left({ }^{13} \mathrm{C} /{ }^{12} \mathrm{C}, \delta^{13} \mathrm{C}\right)$ are a function of the ratio of dissolved inorganic carbon. The stable isotope ratios of seawater, on the other hand, are determined by the interplay of various factors (e.g. evaporation, sea-ice formation, productivity). Therefore, $\delta^{18} \mathrm{O}$ values of fossil planktic foraminiferal shells have been widely used to estimate sea surface temperatures (e.g. Kellogg et al., 1978; Erez and Luz, 1983), salinity (e.g. Duplessy et al., 1992) and ocean stratification (Simstich et al., 2003). Planktic $\delta^{13} \mathrm{C}$ records are generally assumed to reflect changes in palaeoproductivity and ventilation of surface and near-surface waters (Duplessy, 1978). Several studies of living planktic foraminifera showed that these protozoa do not calcify in equilibrium with the ambient sea water (Shackleton et al., 1973; Vergnaud Grazzini, 1976; Kahn, 1979; Kohfeld et al., 1996; Bauch et al., 1997; Volkmann and Mensch, 2001) and that the stable isotope composition of their tests is influenced not only by regional effects but also by numerous other chemical (e.g. pH, carbonate ion concentration) and biological (e.g. symbiont photosynthesis, metabolic activity, test weight) factors. Increasing $\mathrm{pH}$ 

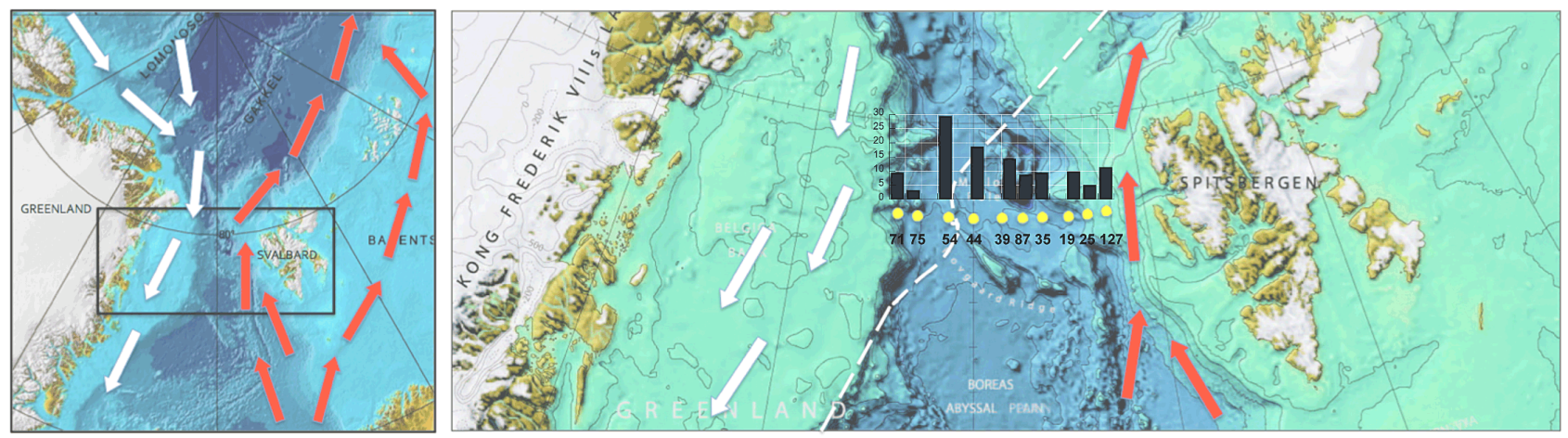

Figure 1. Map and schematic surface ocean circulation of the study area (red arrows: West Spitsbergen Current, white arrows: East Greenland Current). The enlarged part shows the sampled stations (yellow dots). Bars represent absolute abundances (ind $\mathrm{m}^{-3}$ water) of planktic foraminifera in the upper $500 \mathrm{~m}$ of the water column along the transect at $78^{\circ} 50^{\prime} \mathrm{N}$ across the Fram Strait. The white dashed line shows the position of the sea-ice margin at the position of the transect during the sampling period (shipboard observation and satellite data from the US National Oceanic and Atmospheric Administration). Map source: International Bathymetric Chart of the Southern Ocean (Jakobsson et al., 2012).

and carbonate ion concentrations are known to decrease both carbon and oxygen stable isotope ratios (Spero et al., 1997; Bauch et al., 2002), while the presence of symbionts causes depletion in ${ }^{18} \mathrm{O}$ and an increase in $\delta^{13} \mathrm{C}$ values of the shells (Spero and Deniro, 1987). A higher metabolic rate, characteristic for earlier ontogenetic stages (Hemleben et al., 1989), is associated with a discrimination against heavy isotopes (McConnaughey, 1989). Furthermore, planktic foraminifera are assumed to migrate in the water column during ontogeny (Berberich, 1996; Schiebel and Hemleben, 2005) and form their secondary calcite crust while descending into deeper layers (Simstich et al., 2003). Heavier, encrusted individuals are reported to have higher $\delta^{18} \mathrm{O}$ and lower $\delta^{13} \mathrm{C}$ values (Kohfeld et al., 1996; Bauch et al., 1997; Volkmann and Mensch, 2001; Simstich et al., 2003). Combinations of these and other factors make the fossil record difficult to interpret. For example, while both increasing temperature and symbiont activity tend to decrease the $\delta^{18} \mathrm{O}$ value, at the same time both of them can increase the test weight (Hecht, 1976; Spero, 1992), and thereby also indirectly increase the ${ }^{18} \mathrm{O} /{ }^{16} \mathrm{O}$ ratio. Thus, it is essential for an improved interpretation of isotopic records from sediment cores to have detailed knowledge on how modern environmental parameters influence the stable isotope composition of living foraminifera and, to which degree the isotopic composition of their shells reflects the composition of the ambient sea water.

Here we report on results from isotopic analyses to investigate the effects of environmental factors on the isotopic composition of polar planktic foraminifera. Our study was performed in the Fram Strait that connects the Arctic and North Atlantic Oceans and comprises strong oceanographic contrasts (Fig. 1). On an E-W transect between the Svalbard and Greenland margins, the upper water column and sediment surface were sampled for planktic foraminifera species Neogloboquadrina pachyderma (Ehrenberg, 1861) and Tur- borotalita quinqueloba (Natland, 1983). The stable oxygen and carbon isotope compositions of net-sampled tests are compared to the isotope data of ambient seawater and to that of tests from sediment surface samples. Possible reasons for the revealed discrepancies are discussed. Findings about the species assemblage and depth distribution of foraminifera from the same samples are discussed in Pados and Spielhagen (2014).

\section{Hydrographical setting}

The Fram Strait is the only deep passage between the Arctic Ocean and the rest of the world ocean, supplying the Arctic Ocean with waters of North Atlantic origin. The oceanography is dominated by two major surface current systems: the northward flowing West Spitsbergen Current (WSC) carries warm and saline water masses, while in the East Greenland Current (EGC) cold and fresh polar waters exit the Arctic Ocean (Johannessen, 1986). The upper $500 \mathrm{~m}$ of the WSC are dominated by Atlantic Water (Rudels et al., 1999), characterized by temperatures higher than $0.5^{\circ} \mathrm{C}$ and salinities above 34.5 (Jones, 2001). In the western part of the strait the upper $200 \mathrm{~m}$ are characterized by temperatures below $0^{\circ} \mathrm{C}$ and salinities between 32 and 34 . In the summer, as a result of ice melt, the surface waters have even lower salinities (below 32). A well-developed halocline separates the polar waters from the Atlantic Layer found between 200 and $500 \mathrm{~m}$ (Rudels et al., 2000). The interaction between these two water masses controls the sea-ice coverage in the strait. In summer the ice cover usually extends from Greenland to the East Greenland shelf edge but it can intrude also into the eastern part of the strait in the case of extremely cold winter/spring conditions (Dickson et al., 2000). 


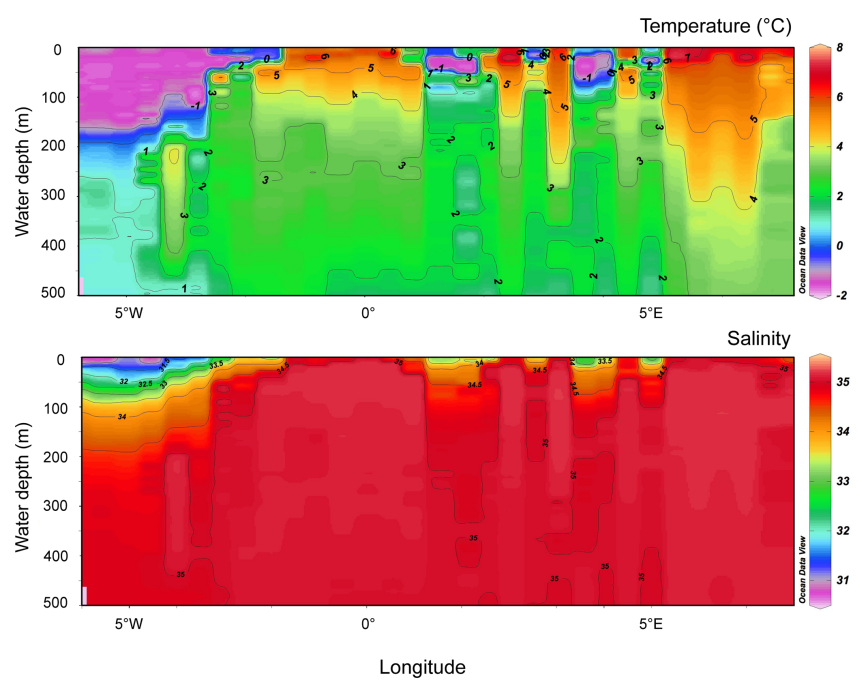

Figure 2. Temperature and salinity of the water column in the upper $500 \mathrm{~m}$ along a transect at $78^{\circ} 50^{\prime} \mathrm{N}$ across the Fram Strait. Data obtained by conductivity-temperature-density (CTD) measurements during the expedition ARK-XXVI/1 (Beszczynska-Möller and Wisotzki, 2012). The figure comprises data obtained from 30 CTD stations, equally distributed along the transect.

The oceanographic system is highly variable and the surface distribution of polar waters can change on a daily timescale (e.g. Beszczynska-Möller et al., 2011). Oceanographic measurements during cruise ARK-XXVI/1 (Beszczynska-Möller and Wisotzki, 2012) provide a detailed profile across the Fram Strait at the time of sampling (Fig. 2). The upper $500 \mathrm{~m}$ of the WSC were characterized by salinities near 35 and temperatures between 4 and $2{ }^{\circ} \mathrm{C}$. At the surface an approx. $100 \mathrm{~m}$ thick, warm layer was observed, with temperatures up to $7-8^{\circ} \mathrm{C}$. During the time of sampling, at 2 and $4^{\circ} \mathrm{E}$ (stations 39 and 35), cold and fresh water masses intruded into the upper 50-100 m of this layer. After 1 week these water masses were no longer present at the same locations (see water column properties at $3^{\circ} \mathrm{E}$ (station 87) that was sampled 8 days later), in agreement with high variability of oceanic fluxes in this region (Beszczynska-Möller et al., 2011). In the western part of the strait and in the EGC, the polar waters extended down to $\sim 200 \mathrm{~m}$ water depth and had salinities around 33 and an average temperature of $-1.5^{\circ} \mathrm{C}$ at the time of the sampling (Fig. 2). Here, on the very surface low salinities $(\sim 30)$ were found that is probably caused by melt water. The polar waters were mainly ice-covered. Below $\sim 200 \mathrm{~m}$ water depth submerged warmer and salty Atlantic waters were found. The sea-ice margin over the position of the transect was located at $\sim 2^{\circ} \mathrm{W}$ during the sampling period.

\section{Material and methods}

Plankton tow, sediment surface and water samples used in this study were obtained during expedition ARK-XXVI/1 with research vessel Polarstern in June/July 2011 in the Fram Strait. Samples were collected at 10 stations along a transect at $78^{\circ} 50^{\prime} \mathrm{N}$ across the Fram Strait (Fig. 1, Table 1). Plankton samples were collected by a MultiNet sampler (net opening $0.5 \mathrm{~m}^{2}$, Hydro-Bios, Kiel, Germany); the nets of $63 \mu \mathrm{m}$ mesh size were towed vertically at regular depth intervals (500-300, 300-200, 200-100, 100-50, and 50-0 m). Sediment surface samples were obtained from multicorer deployments at the same stations. Sample collection and handling procedures are described in detail by Pados and Spielhagen (2014).

For stable isotope analysis 10-25 specimens of Neogloboquadrina pachyderma and 10 specimens of Turborotalita quinqueloba were picked from the $>100 \mu \mathrm{m}$ fraction (plankton samples) and from the $100-250 \mu \mathrm{m}$ fraction (sediment samples). The number of picked tests was restricted by the number of available, same-sized and clearly identifiable shells. In the case of $N$. pachyderma we follow the species concept of Darling et al. (2006) and we differentiate between $N$. pachyderma and $N$. incompta by coiling direction. However, we have to emphasize that we did not genetically analyse the samples, and for isotopical analyses we have used left-coiling specimens only. Thus, according to Darling et al. (2006) the picked tests may genetically be to a very minor amount $N$. incompta. The oxygen and carbon isotope analysis of foraminiferal calcite was performed at the GEOMAR Stable Isotope Lab using a Finnigan-MAT 253 mass spectrometer system connected to a Kiel IV Carbonate Preparation Device.

Temperature and salinity of the water column were measured by a conductivity-temperature-depth (CTD) profiler (Beszczynska-Möller and Wisotzki, 2012), immediately before the deployment of plankton tows. Data of ice coverage were obtained by shipboard observations. Water samples for stable isotope analyses were taken from the rosette sampler, immediately after arriving on the deck to minimize the exchange of contained $\mathrm{CO}_{2}$ with the atmosphere. Water samples for $\delta^{13} \mathrm{C}$ analysis $(100 \mathrm{~mL})$ were drafted carefully into glass bottles without sputtering and thus avoiding bubbles. Samples were immediately poisoned with $\mathrm{HgCl}_{2}(0.2 \mathrm{~mL})$ to stop biochemical reactions, which may alter the carbon isotopic composition of $\mathrm{CO}_{2}$, and bottles were then sealed by aluminium caps with high-density butyl-rubber plugs. Water samples for $\delta^{18} \mathrm{O}$ analysis $(50 \mathrm{~mL})$ were filled into glass bottles and sealed by plastic screw-on caps. The oxygen and carbon isotope mass ratios of the water samples were measured in the stable isotope laboratories of AWI Potsdam with a Finnigan-MAT Delta-S mass spectrometer with two coupled equilibration units $\left(\delta^{18} \mathrm{O}\right)$ and of MARUM (Bremen) using a Gasbench coupled to a MAT 252 mass spectrometer $\left(\delta^{13} \mathrm{C}_{\text {DIC }}\right)$, with a precision and accuracy of at least \pm 0.1 and 
Table 1. List of the stations sampled during cruise ARK-XXVI/1 in June/July 2011.

\begin{tabular}{llllll}
\hline Station & Latitude & Longitude & Water depth & Date & Ice cover \\
\hline PS78-19 & $78^{\circ} 49.84^{\prime} \mathrm{N}$ & $6^{\circ} 0.69^{\prime} \mathrm{E}$ & $2464 \mathrm{~m}$ & 25.06 .11 & no \\
PS78-25 & $78^{\circ} 49.962^{\prime} \mathrm{N}$ & $7^{\circ} 0.077^{\prime} \mathrm{E}$ & $1465 \mathrm{~m}$ & 26.06 .11 & no \\
PS78-35 & $78^{\circ} 49.772^{\prime} \mathrm{N}$ & $3^{\circ} 58.380^{\prime} \mathrm{E}$ & $2335 \mathrm{~m}$ & 28.06 .11 & no \\
PS78-39 & $78^{\circ} 50.09^{\prime} \mathrm{N}$ & $1^{\circ} 54.56^{\prime} \mathrm{E}$ & $2554 \mathrm{~m}$ & 28.06 .11 & no \\
PS78-44 & $78^{\circ} 49.972^{\prime} \mathrm{N}$ & $0^{\circ} 4.630^{\prime} \mathrm{E}$ & $2636 \mathrm{~m}$ & 29.06 .11 & no \\
PS78-54 & $78^{\circ} 50.02^{\prime} \mathrm{N}$ & $2^{\circ} 0.21^{\prime} \mathrm{W}$ & $2714 \mathrm{~m}$ & 01.07 .11 & ice margin \\
PS78-71 & $78^{\circ} 49.66^{\prime} \mathrm{N}$ & $5^{\circ} 20.99^{\prime} \mathrm{W}$ & $684 \mathrm{~m}$ & 04.07 .11 & ice covered \\
PS78-75 & $78^{\circ} 49.74^{\prime} \mathrm{N}$ & $3^{\circ} 55.44^{\prime} \mathrm{W}$ & $1978 \mathrm{~m}$ & 04.07 .11 & ice covered \\
PS78-87 & $78^{\circ} 50.44^{\prime} \mathrm{N}$ & $3^{\circ} 0.19^{\prime} \mathrm{E}$ & $2454 \mathrm{~m}$ & 06.07 .11 & no \\
PS78-127 & $78^{\circ} 49.84^{\prime} \mathrm{N}$ & $8^{\circ} 1.33^{\prime} \mathrm{E}$ & $1019 \mathrm{~m}$ & 10.07 .11 & no \\
\hline
\end{tabular}

$\pm 0.15 \%$ ofor $\delta^{18} \mathrm{O}$ (Meyer et al., 2000) and $\delta^{13} \mathrm{C}_{\mathrm{DIC}}$, respectively.

"Equilibrium calcite values" $\left(\delta_{\mathrm{c}}\right)$ were calculated for the water samples between sea surface and $500 \mathrm{~m}$ water depth from actual $\delta^{18} \mathrm{O}\left(\delta_{\mathrm{w}}\right)$ and temperature $(T)$ measurements according to the so-called "palaeotemperature equation" of O’Neil et al. (1969):

$T\left({ }^{\circ} C\right)=16.9-4.38\left(\delta_{\mathrm{c}}-\delta_{\mathrm{w}}\right)+0.1\left(\delta_{\mathrm{c}}-\delta_{\mathrm{w}}\right)^{2}$,

where $\delta_{\mathrm{c}}$ and $\delta_{\mathrm{w}}$ are the stable oxygen isotope values of the calcite and the water on the PDB scale, respectively. Isotope measurements of water are presented using Standard Mean Ocean Water (SMOW) as a standard. $\delta^{18} \mathrm{O}$ (SMOW) was converted to $\delta^{18} \mathrm{O}$ (PDB) for the palaeotemperature equation according to Bemis et al. (1998):

$\delta^{18} \mathrm{O}(\mathrm{PDB})=0.9998 \delta^{18} \mathrm{O}(\mathrm{SMOW})-0.2 \%$ 。

Weighted averages of the stable isotope results for each station were calculated using the standing stock (sum of isotope values for each interval multiplied with the concentration of foraminifera in depth interval/sum concentrations in all intervals; see Bauch et al., 1997). Carbonate ion concentrations from our sampling area in the Fram Strait at about $78.5^{\circ} \mathrm{N}$ were extracted from the hydrographic database CARINA (CARbon dioxide IN the Atlantic Ocean; http://cdiac. ornl.gov/oceans/CARINA/) from expeditions on RV Hudson and RV Knorr in 1982 and 2002, respectively.

\section{Results}

\subsection{Water column properties}

\subsubsection{Stable isotopes in the upper water column}

In general, oxygen isotope composition of water is roughly linearly correlated to salinity (Fig. 3). Both change along the transect with lowest values at the surface and are continuously increasing with depth. Surface $\delta^{18} \mathrm{O}$ and salinity are lowest in the west and highest in the east (Fig. 4). The vertical $\delta^{18} \mathrm{O}$ profiles of the two westernmost stations show strong similarities with the vertical profiles of stations 35 and 39 ( 4 and $2^{\circ} \mathrm{E}$, respectively) where during the time of sampling cold and fresh water masses intruded into the warm surface waters. At these four stations extremely low salinity and $\delta^{18} \mathrm{O}$ values mark polar waters at the surface that reach from the surface down to $\sim 200 \mathrm{~m}$ water depth at stations 75 and 71 ( 4 and $5^{\circ} \mathrm{W}$, respectively) and to $\sim 100 \mathrm{~m}$ water depth at stations 39 and 35 ( 2 and $4^{\circ} \mathrm{E}$, respectively). Below the surface layers the Atlantic waters are characterized by relatively high and constant $\delta^{18} \mathrm{O}$ values of about $+0.3 \%$ (Fig. 4). The remaining six stations reveal more scatter: we found a slight increase from the surface to $25 \mathrm{~m}$ water depth, then a decrease to $75-100 \mathrm{~m}$ depth, followed by invariant $\delta^{18} \mathrm{O}$ values of the Atlantic Layer (Table 2). When evaluating average values over the upper $500 \mathrm{~m}$ of the water column, the two westernmost stations (75 and 71) yield the lowest average values $(-0.41 \pm 0.94$ and $-0.84 \pm 1.16 \%$, respectively) while the highest average value $(+0.34 \pm 0.03 \%)$ is observed at $3^{\circ} \mathrm{E}$ at station 87.

The vertical variation of the carbon isotope composition of the dissolved inorganic carbon (DIC) in the upper $500 \mathrm{~m}$ of the water column is rather small. The $\delta^{13} \mathrm{C}_{\mathrm{DIC}}$ values have an average value of about $+1.04 \%$ with a standard deviation of 0.24 . Surface waters always yield heavier values, decreasing down to $\sim 100 \mathrm{~m}$ water depth followed by relatively constant values down to $500 \mathrm{~m}$ water depth (Fig. 4, Table 2).

\subsubsection{Equilibrium calcite values}

The equilibrium calcite values calculated from $\delta^{18} \mathrm{O}$ and temperature of seawater increase constantly with depth in the eastern part of the strait, while at the stations at 4 and $5^{\circ} \mathrm{W}$, in the western part of the strait, a stronger increase is observed from the surface down to $150 \mathrm{~m}$ water depth, followed by a slight decrease. A similar pattern, though in a narrower range, can be found at 4 and $2^{\circ} \mathrm{E}$, in the middle of the strait, where near the surface unusually low temperatures of the water were recorded during the sampling period (Fig. 5, Table 2). 
Table 2. $\delta^{18} \mathrm{O}, \delta^{13} \mathrm{C}$ and equilibrium calcite values in the upper $500 \mathrm{~m}$ of the water column.

\begin{tabular}{|c|c|c|c|c|}
\hline Station & Depth (m) & $\delta^{18} \mathrm{O}(\% \circ \mathrm{SMOW})$ & $\delta^{13} \mathrm{C}(\% \circ \mathrm{PDB})$ & Equ. calc. \\
\hline \multirow{12}{*}{ PS78-19 } & 0 & 0.29 & 1.63 & 2.90 \\
\hline & 25 & 0.38 & 1.71 & 3.01 \\
\hline & 50 & 0.4 & 1.39 & 3.32 \\
\hline & 75 & 0.34 & 0.92 & 3.44 \\
\hline & 100 & 0.21 & 0.66 & 3.33 \\
\hline & 125 & & 0.95 & \\
\hline & 150 & 0.28 & 1.06 & 3.49 \\
\hline & 200 & 0.31 & 0.84 & 3.55 \\
\hline & 250 & 0.21 & & 3.50 \\
\hline & 300 & 0.31 & 0.95 & 3.66 \\
\hline & 400 & 0.23 & 1.10 & 3.77 \\
\hline & 500 & 0.27 & 1.06 & 3.91 \\
\hline \multirow{12}{*}{ PS78-25 } & 0 & 0.32 & 0.89 & 2.70 \\
\hline & 25 & 0.37 & 0.92 & 2.73 \\
\hline & 50 & 0.33 & 0.96 & 3.24 \\
\hline & 75 & 0.3 & 0.98 & 3.29 \\
\hline & 100 & 0.31 & 0.86 & 3.36 \\
\hline & 125 & 0.3 & 0.83 & 3.44 \\
\hline & 150 & 0.28 & 0.97 & 3.47 \\
\hline & 200 & 0.29 & 0.90 & 3.50 \\
\hline & 250 & & & \\
\hline & 300 & 0.26 & 0.95 & 3.53 \\
\hline & 400 & 0.25 & 0.99 & 3.70 \\
\hline & 500 & 0.25 & 0.94 & 3.94 \\
\hline \multirow{12}{*}{ PS78-35 } & 0 & -0.98 & 1.30 & 3.06 \\
\hline & 25 & -0.46 & 1.30 & 3.99 \\
\hline & 50 & 0.09 & 1.03 & 4.26 \\
\hline & 75 & 0.23 & 0.96 & 3.62 \\
\hline & 100 & 0.29 & 0.70 & 3.53 \\
\hline & 125 & 0.37 & 0.73 & 3.65 \\
\hline & 150 & 0.29 & 0.99 & 3.63 \\
\hline & 200 & 0.33 & 1.05 & 3.82 \\
\hline & 250 & & & \\
\hline & 300 & 0.33 & 1.01 & 3.81 \\
\hline & 400 & 0.23 & 1.07 & 3.82 \\
\hline & 500 & 0.29 & 1.01 & 4.00 \\
\hline \multirow{12}{*}{ PS78-39 } & 0 & -0.29 & 1.50 & 3.92 \\
\hline & 25 & -0.25 & 1.31 & 4.27 \\
\hline & 50 & 0.06 & 1.21 & 4.64 \\
\hline & 75 & 0.14 & 1.11 & 3.99 \\
\hline & 100 & 0.17 & 0.97 & 4.02 \\
\hline & 125 & 0.22 & 1.05 & 3.82 \\
\hline & 150 & 0.25 & 1.13 & 3.67 \\
\hline & 200 & 0.36 & 1.01 & 3.87 \\
\hline & 250 & & & \\
\hline & 300 & 0.28 & 0.82 & 3.76 \\
\hline & 400 & 0.29 & 0.79 & 3.71 \\
\hline & 500 & 0.28 & 1.09 & 3.80 \\
\hline
\end{tabular}


Table 2. Continued.

\begin{tabular}{|c|c|c|c|c|}
\hline Station & Depth (m) & $\delta^{18} \mathrm{O}(\% \circ \mathrm{SMOW})$ & $\delta^{13} \mathrm{C}(\% \circ \mathrm{PDB})$ & Equ. calc. \\
\hline \multirow{12}{*}{ PS78-44 } & 0 & 0.25 & 1.39 & 2.73 \\
\hline & 25 & 0.38 & 1.16 & 3.03 \\
\hline & 50 & 0.38 & 1.01 & 3.14 \\
\hline & 75 & 0.3 & 0.88 & 3.19 \\
\hline & 100 & 0.37 & 0.89 & 3.40 \\
\hline & 125 & 0.38 & 0.98 & 3.48 \\
\hline & 150 & 0.31 & 0.96 & 3.45 \\
\hline & 200 & 0.29 & 1.19 & 3.47 \\
\hline & 250 & & & \\
\hline & 300 & 0.28 & 0.88 & 3.60 \\
\hline & 400 & 0.35 & 0.98 & 3.79 \\
\hline & 500 & 0.28 & 1.14 & 3.89 \\
\hline \multirow{12}{*}{ PS78-54 } & 0 & 0.33 & 1.68 & 4.41 \\
\hline & 25 & 0.41 & 1.61 & 4.69 \\
\hline & 50 & 0.37 & 0.94 & 3.06 \\
\hline & 75 & 0.32 & 0.95 & 3.21 \\
\hline & 100 & 0.37 & 1.06 & 3.38 \\
\hline & 125 & 0.36 & 0.94 & 3.44 \\
\hline & 150 & 0.36 & 1.10 & 3.49 \\
\hline & 200 & 0.25 & 1.09 & 3.46 \\
\hline & 250 & & & \\
\hline & 300 & 0.21 & 0.90 & 3.49 \\
\hline & 400 & 0.36 & 1.04 & 3.72 \\
\hline & 500 & 0.3 & 0.87 & 3.77 \\
\hline \multirow{12}{*}{ PS78-71 } & 0 & -2.63 & 1.49 & 1.67 \\
\hline & 25 & -2.4 & 1.50 & 2.15 \\
\hline & 50 & -2.18 & 1.23 & 2.38 \\
\hline & 75 & -1.41 & 1.12 & 3.13 \\
\hline & 100 & -1 & 1.11 & 3.49 \\
\hline & 125 & -0.52 & 1.02 & 3.98 \\
\hline & 150 & -0.25 & 1.09 & 4.24 \\
\hline & 200 & 0.04 & 1.13 & 4.15 \\
\hline & 250 & & & \\
\hline & 300 & 0.36 & 0.94 & 4.13 \\
\hline & 400 & 0.37 & 0.95 & 4.07 \\
\hline & 500 & 0.4 & 1.18 & 4.34 \\
\hline \multirow{12}{*}{ PS78-75 } & 0 & -2.2 & 1.34 & 2.31 \\
\hline & 25 & -1.85 & 0.96 & 2.70 \\
\hline & 50 & -1.2 & 1.15 & 3.34 \\
\hline & 75 & -0.51 & 1.10 & 3.94 \\
\hline & 100 & -0.27 & 1.11 & 4.05 \\
\hline & 125 & -0.09 & 0.91 & 4.16 \\
\hline & 150 & 0.21 & 0.86 & 4.24 \\
\hline & 200 & 0.36 & 0.91 & 3.34 \\
\hline & 250 & & & \\
\hline & 300 & 0.37 & 1.01 & 3.46 \\
\hline & 400 & 0.34 & 0.87 & 3.56 \\
\hline & 500 & 0.36 & 0.99 & 4.19 \\
\hline
\end{tabular}


Table 2. Continued.

\begin{tabular}{ccccc}
\hline Station & Depth $(\mathrm{m})$ & $\delta^{18} \mathrm{O}(\%$ SMOW $)$ & $\delta^{13} \mathrm{C}(\%$ PDB $)$ & Equ. calc. \\
\hline & 0 & 0.31 & 1.54 & 2.58 \\
& 25 & 0.38 & 1.20 & 2.51 \\
& 50 & 0.35 & 1.08 & 2.94 \\
PS78-87 & 0.3 & 1.02 & 3.02 \\
& 15 & 0.36 & 0.64 & 3.19 \\
& 125 & 0.35 & 0.70 & 3.27 \\
& 150 & 0.37 & 0.69 & 3.38 \\
& 200 & 0.29 & 0.86 & 3.46 \\
& 250 & & & \\
& 300 & 0.36 & 0.79 & 3.67 \\
& 400 & 0.33 & 0.64 & 3.74 \\
& 500 & 0.37 & 0.87 & 3.87 \\
\hline & 0 & 0.34 & 1.64 & 2.60 \\
PS78-127 & 0.49 & 1.31 & 2.64 \\
& 25 & 0.4 & 0.95 & 2.91 \\
& 50 & 0.21 & 0.85 & 2.76 \\
& 15 & 0.38 & 0.87 & 2.96 \\
& 100 & 0.32 & 0.93 & 2.94 \\
& 150 & 0.36 & 0.88 & 3.03 \\
& 200 & 0.34 & 0.94 & 3.07 \\
& 300 & 0.28 & 0.96 & 3.22 \\
& 400 & 0.32 & 1.00 & 3.40 \\
500 & 0.3 & & 3.49 \\
\hline
\end{tabular}

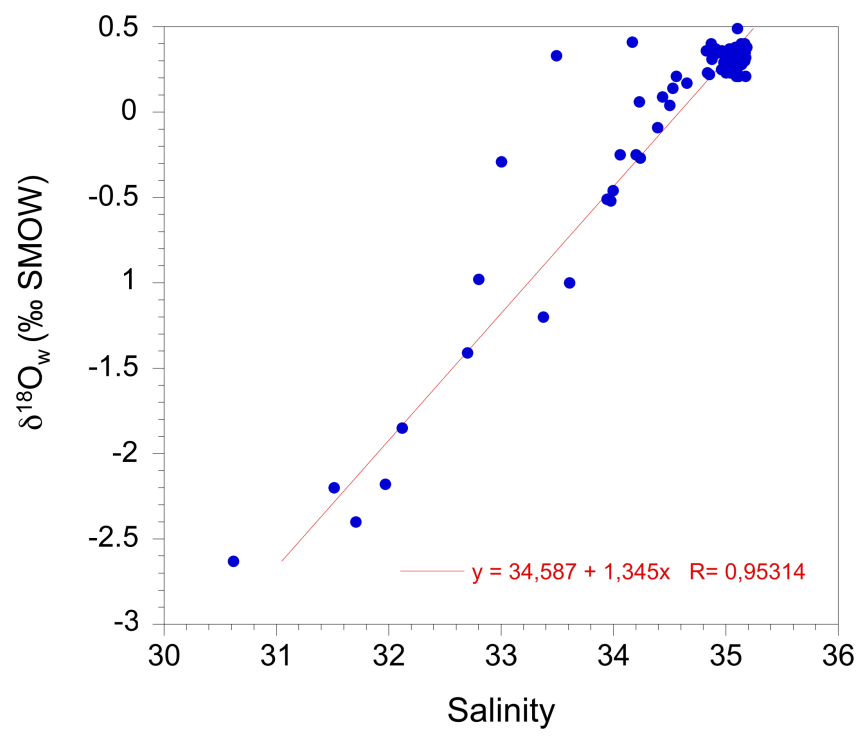

Figure 3. $\delta^{18} \mathrm{O}(\%$ o SMOW) values of the upper $500 \mathrm{~m}$ of the water column vs. salinities (PSU) for the sampled transect at $78^{\circ} 50^{\prime} \mathrm{N}$ across the Fram Strait.

\subsection{Species distribution of planktic foraminifera}

In the Fram Strait the planktic foraminiferal fauna is dominated by polar Neogloboquadrina pachyderma and subpo- lar, symbiont-bearing Turborotalita quinqueloba (Volkmann, 2000; Simstich et al., 2003; Pados and Spielhagen, 2014). N. pachyderma clearly prevails in our samples contributing to the total assemblages with 73-92\% compared to the subpo$\operatorname{lar}$ T. quinqueloba, contributing 5-23\%. The proportion of $N$. pachyderma shows an increasing trend towards the west while $T$. quinqueloba follows an exactly reverse tendency. Both species have maximum absolute abundances between $0-100 \mathrm{~m}$ water depth with a shallower maximum under the ice cover than in the open ocean (Figs. 6, 7). The species assemblage found in the sediment surface was found to correlate best with the living fauna caught between $50-100 \mathrm{~m}$ water depth (Pados and Spielhagen, 2014).

\subsection{Stable isotope composition of foraminifera}

\subsubsection{Neogloboquadrina pachyderma}

The oxygen isotope composition of $N$. pachyderma from sediment surface samples shows lowest values at the three easternmost stations (stations 127, 25, 19; at 8-6 E). The highest value is found in the western part at station 75 , at $4^{\circ} \mathrm{W}$. The sediment surface samples have an average $\delta^{18} \mathrm{O}$ value of $+3.2 \pm 0.3 \%$ (Table 3 ). The plankton samples generally have a lower oxygen isotope composition than the sediment surface samples. The weighted average $\delta^{18} \mathrm{O}$ values at each station are ranging from $-0.7 \pm 1.7 \%$ o to $+3.3 \pm 0.2 \%$ over 


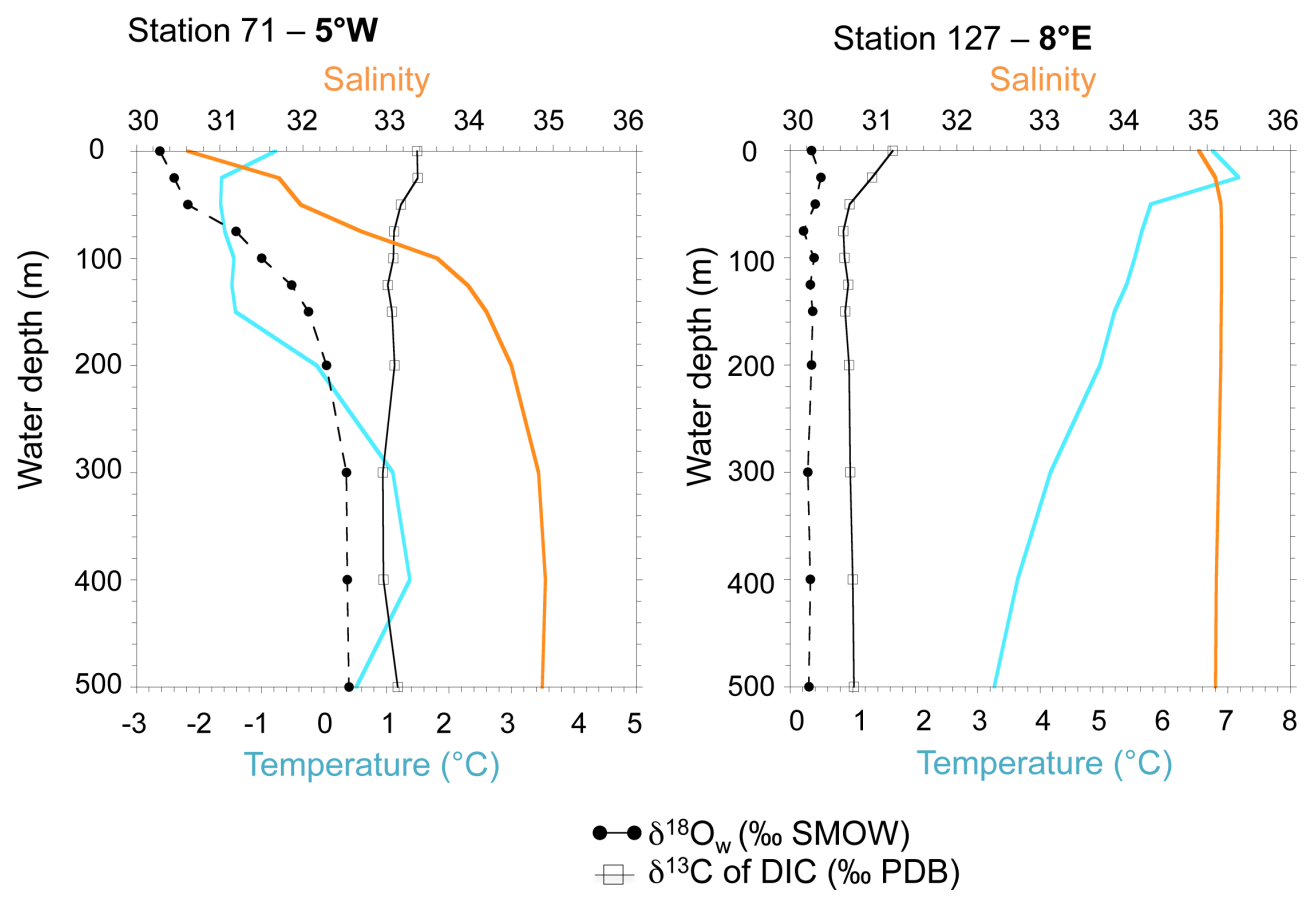

Figure 4. Salinity, temperature, $\delta^{18} \mathrm{O}(\% \circ \mathrm{SMOW})$ and $\delta^{13} \mathrm{C}_{\mathrm{DIC}}(\% \circ \mathrm{PDB})$ profiles of the upper $500 \mathrm{~m}$ of the water column from the westernmost and easternmost stations sampled along a transect at $78^{\circ} 50^{\prime} \mathrm{N}$ across the Fram Strait. The lower $x$-axis represents the axis for both temperatures and isotope values.

the whole transect. There is no clear east-west difference and the stations in the middle of the strait (at $4^{\circ} \mathrm{E}, 2^{\circ} \mathrm{E}$ and at $2^{\circ} \mathrm{W}$ ) yield the highest values (Fig. 8). The vertical distribution of $\delta^{18} \mathrm{O}$ does not show a well-pronounced trend. The only clearly recognizable pattern is that values in the depth interval of $0-50 \mathrm{~m}$ are usually lower than those from the interval $50-100 \mathrm{~m}$ (an exception is station 54 where the surface waters yielded slightly heavier $\delta^{18} \mathrm{O}$ values) (Fig. 5, Table 4).

The $\delta^{13} \mathrm{C}$ values of $N$. pachyderma from sediment surface samples are relatively constant and have an average value of $+0.5 \pm 0.2 \%$. The lateral distribution of the $\delta^{13} \mathrm{C}$ values from the sediments shows a trend similar to the $\delta^{18} \mathrm{O}$ results: the easternmost stations have the lowest values $(+0.09$, +0.15 and $+0.4 \%$ at 8,7 and $6^{\circ} \mathrm{E}$, respectively) while the highest $(+0.7 \% o)$ is found in the western part of the section, at the sea-ice margin at $2^{\circ} \mathrm{W}$ (Table 3 ). The carbon isotope composition of $N$. pachyderma from plankton tows shows lower values at each station than the $\delta^{13} \mathrm{C}$ values from sediments. The $\delta^{13} \mathrm{C}$ values of plankton samples have a mean of $-0.8 \pm 0.7 \%$ of weighted averages over the whole transect. The plankton samples do not follow the E-W trend found in the coretop samples and both the lowest and the highest values are found at stations in the middle of the transect (at 3 and $2^{\circ} \mathrm{E}$, respectively) (Fig. 8). Vertical $\delta^{13} \mathrm{C}$ profiles of the plankton samples show increasing values from the sea surface down to the depth interval of 100-200 m (exceptions are the stations at $8^{\circ} \mathrm{E}, 3^{\circ} \mathrm{E}$ and $5^{\circ} \mathrm{W}$ where maximum values lie in the depth interval of $50-100 \mathrm{~m}$ ), followed by a slight decrease to 300-500 m (Fig. 5, Table 4).

\subsubsection{Turborotalita quinqueloba}

Both oxygen and carbon isotope compositions of T. quinqueloba from sediment surface samples show increasing values from east to west; averaging over the transect $-0.1 \pm 0.2$ and $+2.7 \pm 0.3 \%$, respectively (Table 3 ).

The weighted averages of the $\delta^{18} \mathrm{O}$ and $\delta^{13} \mathrm{C}$ values of net sampled specimens scatter along the stations and do not show any pronounced east-west difference (Fig. 8). The vertical profiles of both parameters show extremely low values near the surface compared to all other depth intervals. The vertical variation of the $\delta^{18} \mathrm{O}$ and $\delta^{13} \mathrm{C}$ values in T. quinqueloba is much bigger than the variation found in $N$. pachyderma (Fig. 9, Table 4). However, it has to be taken into account that the number of specimens available for isotope analysis (on average 10 tests) was rather low and possibly not sufficient to yield reliable results for this thin-walled species. We cannot exclude that the differences in variation are due to a non-systematic error in the isotope measurements of T. quinqueloba. 


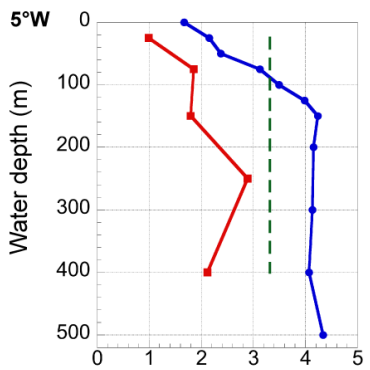

b
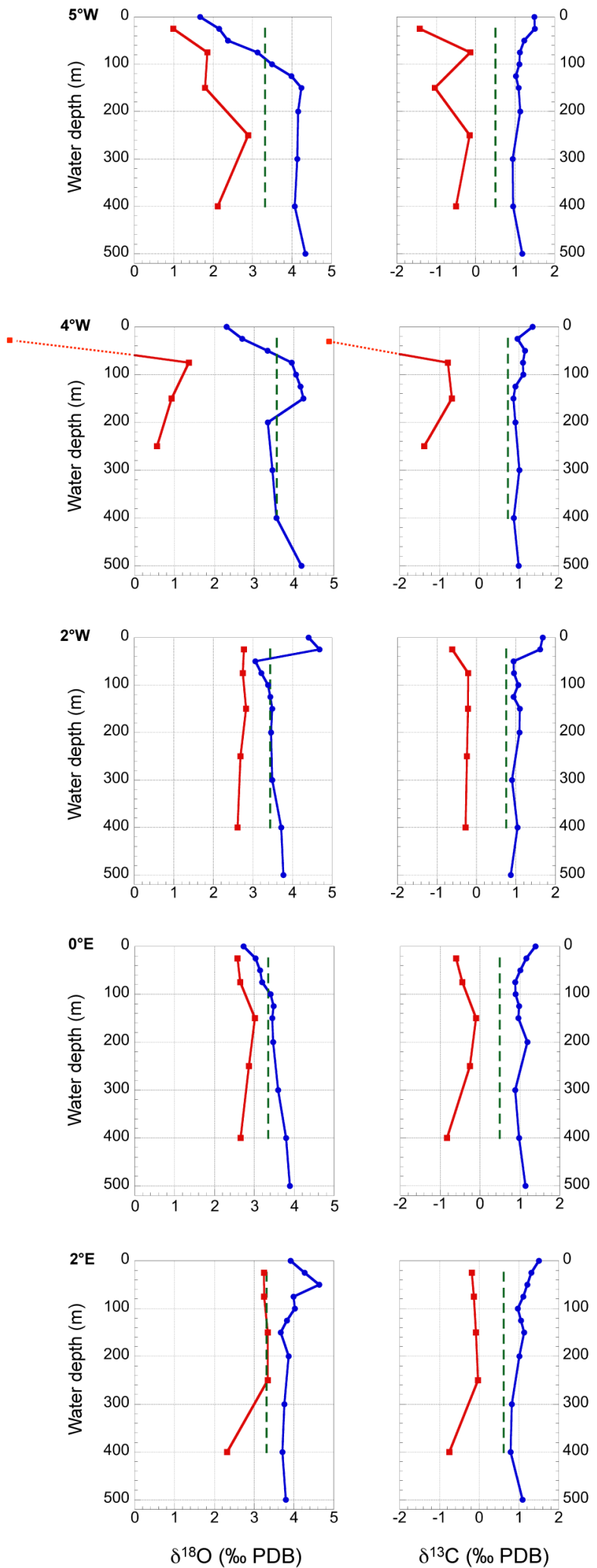

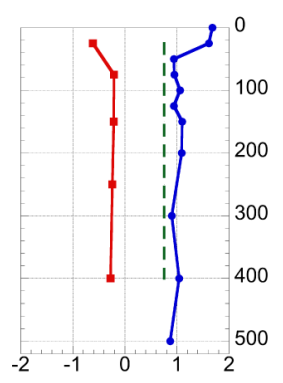

a
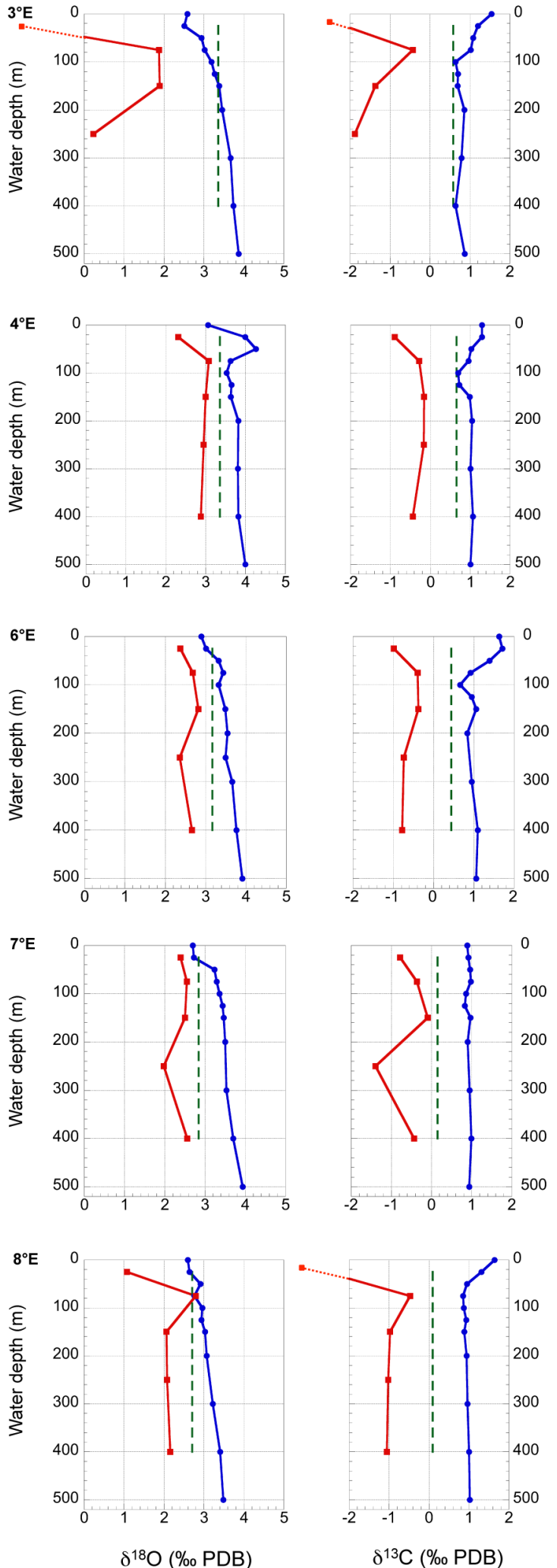

b
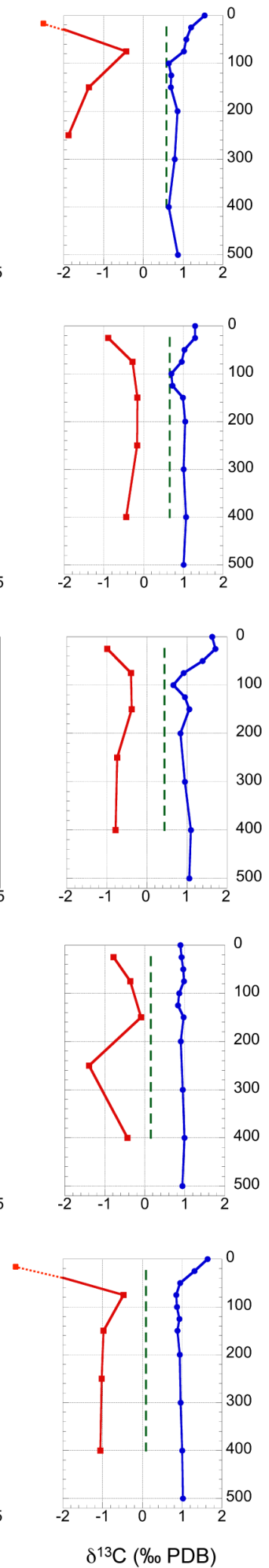

Figure 5. (a) $\delta^{18} \mathrm{O}$ and (b) $\delta^{13} \mathrm{C}$ values of $N$. pachyderma from the water column (red squares) and from the sediment surface (green dashed line). The blue dots indicate (a) the equilibrium calcite and (b) the $\delta^{13} \mathrm{C}_{\text {DIC }}$ profile of the water column. 

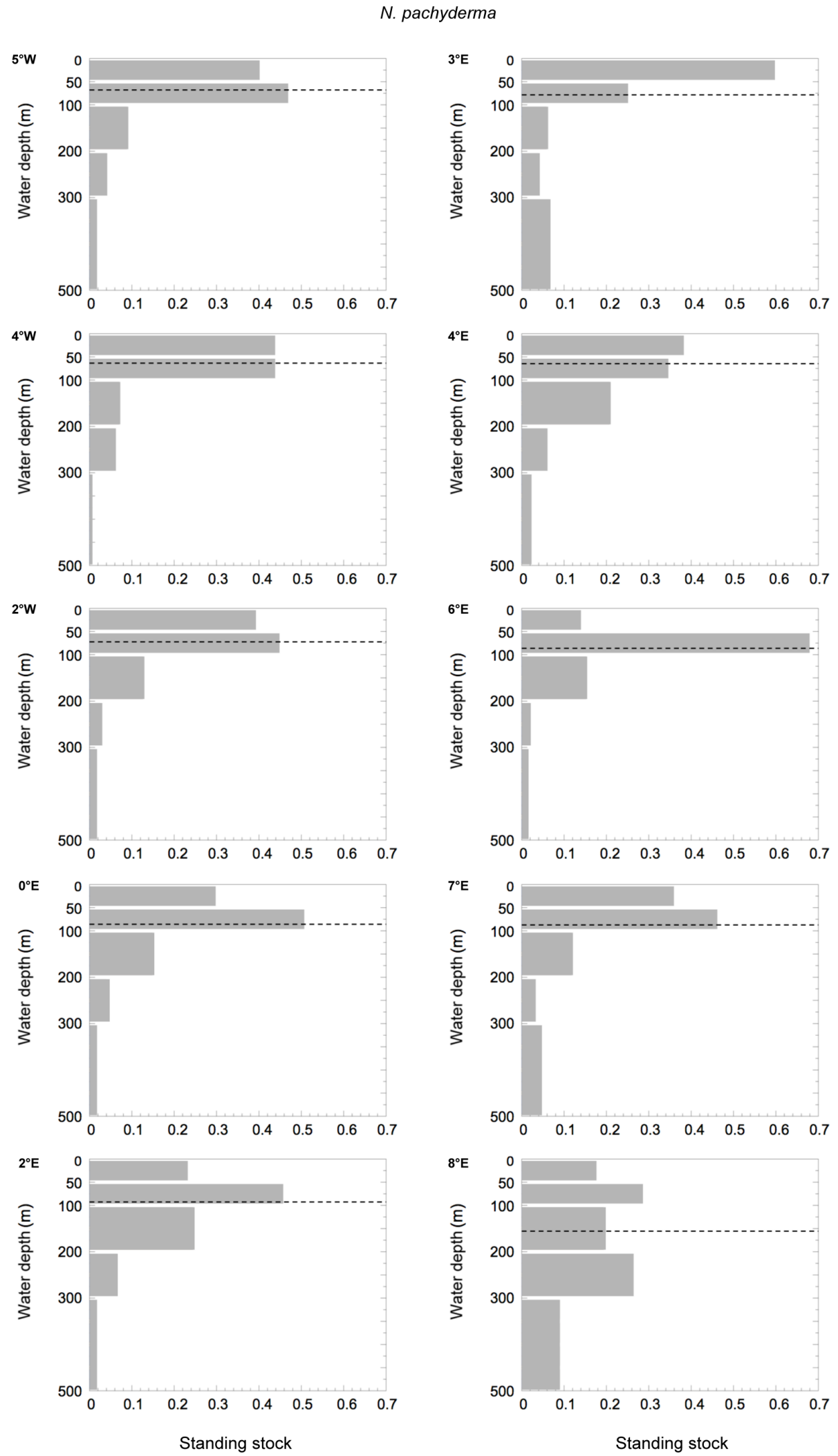

Figure 6. Standing stock of $N$. pachyderma for each sampling interval. The black dashed line indicates the average depth of calcification (calculated from the standing stock). 
T. quinqueloba
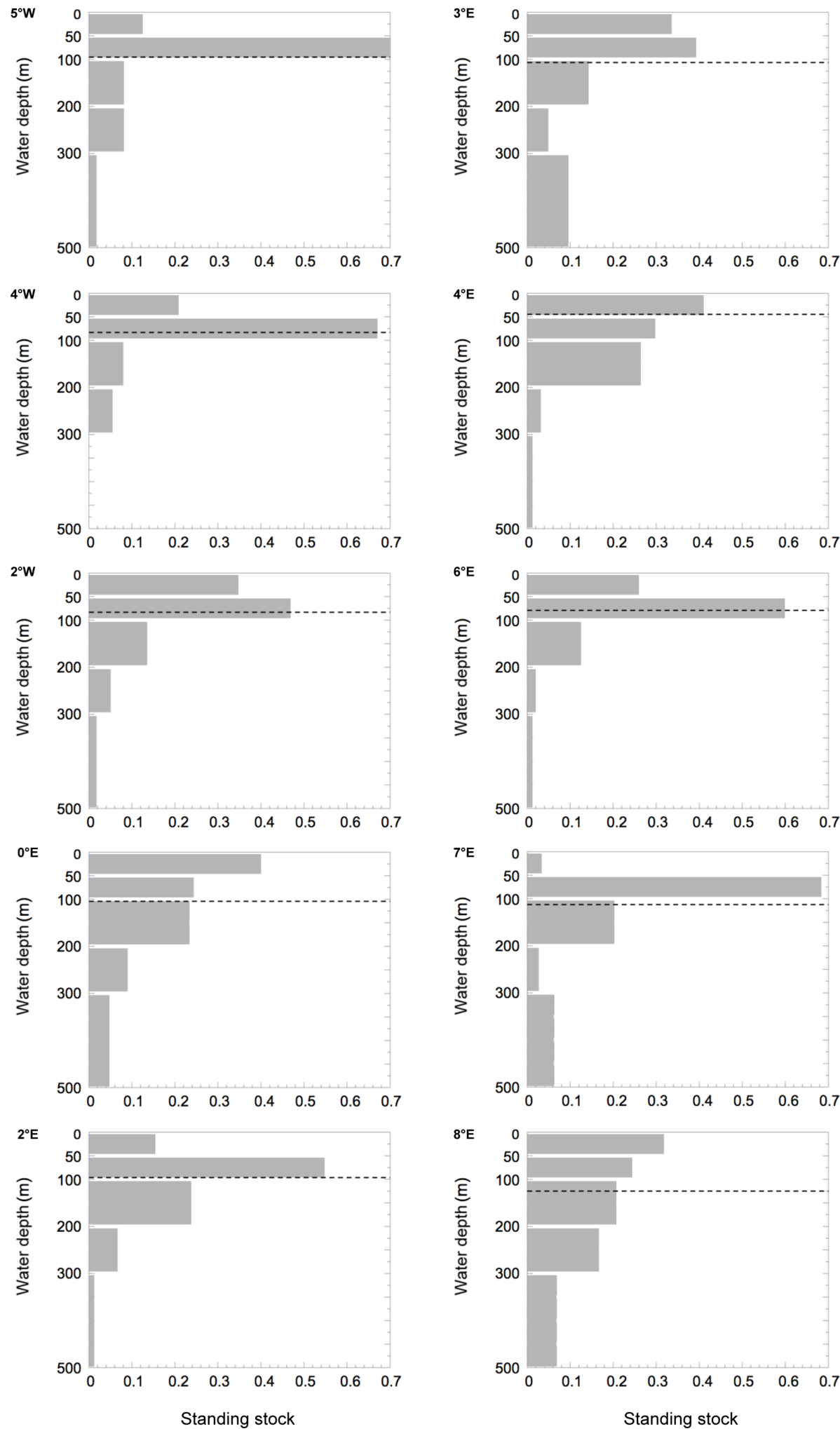

Figure 7. Standing stock of T. quinqueloba for each sampling interval. The black dashed line indicates the average depth of calcification (calculated from the standing stock). 


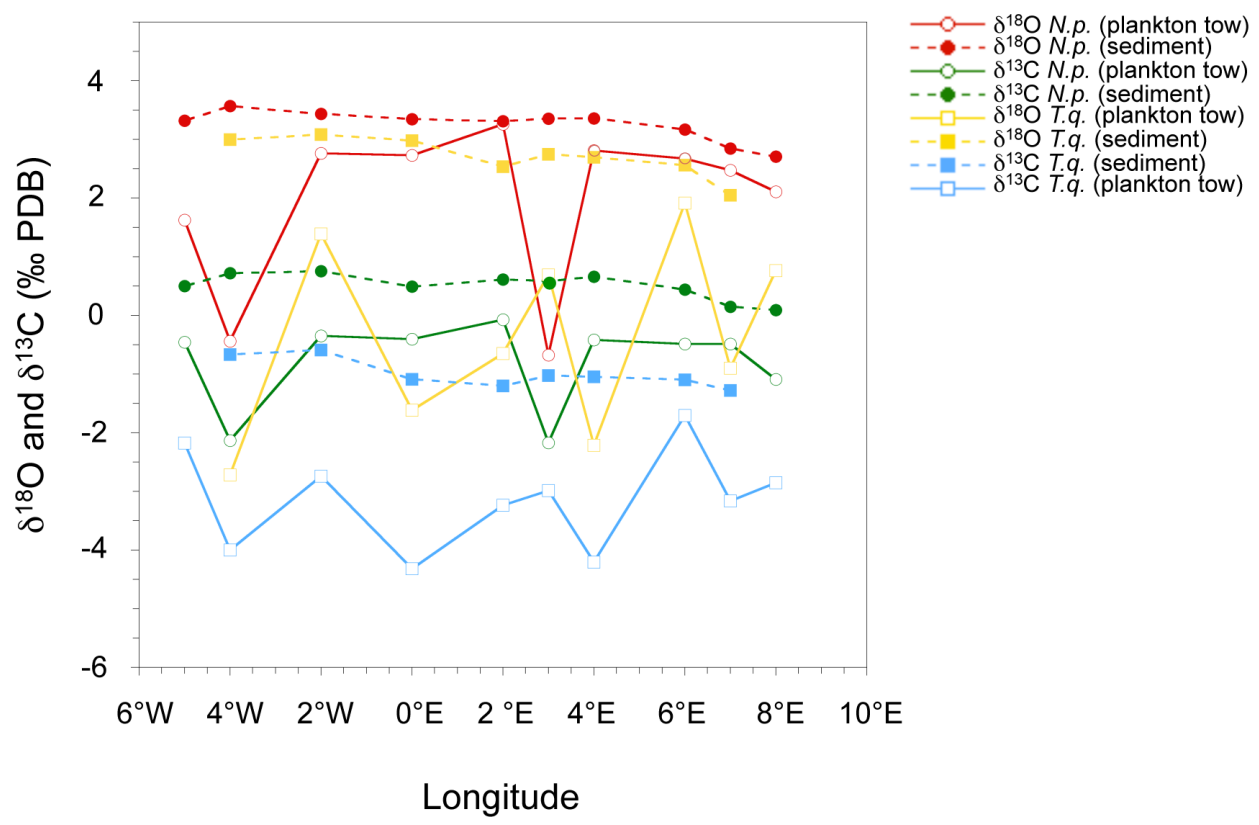

Figure 8. $\delta^{18} \mathrm{O}$ and $\delta^{13} \mathrm{C}$ of $N$. pachyderma (circles) and T. quinqueloba (squares) from the water column (weighted average over the upper $500 \mathrm{~m}$ of the water column; non-filled symbols) and from the sediment surface (filled symbols) along a transect at $78^{\circ} 50^{\prime} \mathrm{N}$ across the Fram Strait.

Table 3. $\delta^{18} \mathrm{O}$ and $\delta^{13} \mathrm{C}$ values of $N$. pachyderma (N. p.) and T. quinqueloba (T. q.) from sediment surface samples.

\begin{tabular}{llllll}
\hline & \multicolumn{2}{c}{$\delta^{18} \mathrm{O}(\% \circ \mathrm{PDB})$} & & \multicolumn{2}{c}{$\delta^{13} \mathrm{C}(\% \circ \mathrm{PDB})$} \\
\cline { 2 - 3 } \cline { 6 - 6 } Station & N. $p$. & T. $q$. & & N. $p$. & T. $q$. \\
\hline PS78-19 & 3.17 & 2.56 & & 0.44 & -1.10 \\
PS78-25 & 2.84 & 2.05 & & 0.15 & -1.28 \\
PS78-35 & 3.36 & 2.70 & & 0.66 & -1.05 \\
PS78-39 & 3.31 & 2.53 & & 0.61 & -1.20 \\
PS78-44 & 3.35 & 2.98 & & 0.49 & -1.09 \\
PS78-54 & 3.44 & 3.08 & & 0.75 & -0.59 \\
PS78-71 & 3.32 & & & 0.50 & \\
PS78-75 & 3.57 & 3.00 & & 0.72 & -0.67 \\
PS78-87 & 3.36 & 2.75 & & 0.58 & -1.02 \\
PS78-127 & 2.71 & & & 0.09 & \\
\hline
\end{tabular}

\section{Discussion}

\subsection{Oxygen isotope values of water samples and foraminifera}

The calculated equilibrium calcite isotope composition represents the potential $\delta^{18} \mathrm{O}$ value of inorganic calcite precipitated in isotopic equilibrium with the surrounding seawater. The offset found between the equilibrium calcite value and the measured $\delta^{18} \mathrm{O}$ value of foraminiferal tests is commonly described as a "vital effect" related to differential isotopic uptake in carbonate organisms compared to equilibrium conditions. The $\delta^{18} \mathrm{O}$ values of living foraminifera in our work area during early summer were consistently lower than the calculated equilibrium calcite values. Part of this offset may certainly result from mesoscale oceanic variability, i.e. short-term changes of salinity and/or temperature due to, e.g. sea-ice formation/melting or local vertical convection. The mean offsets were $-1.5 \pm 1.3 \%$ in Neogloboquadrina pachyderma and $-3.7 \pm 1.7 \%$ in Turborotalita quinqueloba. Based on previously published results, the magnitude of the vital effect in $N$. pachyderma appears to vary regionally. Bauch et al. (1997) reported a consistent offset of $-1.0 \%$ between equilibrium calcite values and $\delta^{18} \mathrm{O}$ data of net-sampled $N$. pachyderma in the Nansen Basin. Volkmann and Mensch (2001) found an average vital effect of $-1.3 \%$ in the Laptev Sea for N. pachyderma and -1.6 and $-1.3 \%$ in the Fram Strait for N. pachyderma and for $T$. 
Table 4. $\delta^{18} \mathrm{O}$ and $\delta^{13} \mathrm{C}$ values of $N$. pachyderma (N. p.) and T. quinqueloba (T. q.) from plankton tows.

\begin{tabular}{|c|c|c|c|c|c|}
\hline \multirow[b]{2}{*}{ Station } & \multirow[b]{2}{*}{ Depth (m) } & \multicolumn{2}{|c|}{$\delta^{18} \mathrm{O}(\% \circ \mathrm{PDB})$} & \multicolumn{2}{|c|}{$\delta^{13} \mathrm{C}\left(\%_{0} \mathrm{PDB}\right)$} \\
\hline & & N. $p$. & T. $q$. & N. p. & T. $q$. \\
\hline \multirow{5}{*}{ PS78-19 } & $0-50$ & 2.38 & & -0.99 & \\
\hline & $50-100$ & 2.69 & 1.96 & -0.40 & -1.64 \\
\hline & $100-200$ & 2.82 & 1.81 & -0.38 & -1.88 \\
\hline & $200-300$ & 2.36 & & -0.74 & \\
\hline & $300-500$ & 2.67 & & -0.78 & \\
\hline \multirow{5}{*}{ PS78-25 } & $0-50$ & 2.40 & & -0.78 & \\
\hline & $50-100$ & 2.55 & -2.85 & -0.37 & -4.25 \\
\hline & 100-200 & 2.51 & 1.64 & -0.10 & -1.72 \\
\hline & $200-300$ & 1.98 & & -1.40 & \\
\hline & $300-500$ & 2.56 & 0.31 & -0.43 & -2.50 \\
\hline \multirow{5}{*}{ PS78-35 } & $0-50$ & 2.32 & -5.54 & -0.89 & -6.13 \\
\hline & $50-100$ & 3.08 & -5.57 & -0.28 & -6.03 \\
\hline & 100-200 & 3.00 & 2.25 & -0.15 & -1.68 \\
\hline & $200-300$ & 2.95 & & -0.16 & \\
\hline & $300-500$ & 2.88 & & -0.44 & \\
\hline \multirow{5}{*}{ PS78-39 } & $0-50$ & 3.25 & -4.99 & -0.19 & -5.79 \\
\hline & $50-100$ & 3.25 & -1.36 & -0.13 & -3.61 \\
\hline & $100-200$ & 3.34 & 1.57 & 0.08 & -1.99 \\
\hline & $200-300$ & 3.34 & & 0.03 & \\
\hline & $300-500$ & 2.32 & & -0.75 & \\
\hline \multirow{5}{*}{ PS78-44 } & $0-50$ & 2.58 & -7.35 & -0.60 & -7.86 \\
\hline & $50-100$ & 2.64 & & -0.44 & \\
\hline & 100-200 & 3.01 & 2.13 & -0.10 & -1.44 \\
\hline & $200-300$ & 2.86 & 0.41 & -0.25 & -2.46 \\
\hline & $300-500$ & 2.65 & -0.51 & -0.83 & -5.78 \\
\hline \multirow{5}{*}{ PS78-54 } & $0-50$ & 2.77 & -0.86 & -0.62 & -5.96 \\
\hline & $50-100$ & 2.75 & 2.46 & -0.21 & -1.22 \\
\hline & 100-200 & 2.83 & 2.20 & -0.21 & -1.56 \\
\hline & $200-300$ & 2.69 & 1.59 & -0.24 & -2.57 \\
\hline & $300-500$ & 2.61 & 2.18 & -0.28 & -1.52 \\
\hline \multirow{5}{*}{ PS78-71 } & $0-50$ & 0.99 & & -0.63 & \\
\hline & $50-100$ & 1.86 & 1.72 & -0.14 & -1.78 \\
\hline & 100-200 & 1.80 & -1.93 & -1.04 & -3.84 \\
\hline & $200-300$ & 2.89 & 0.85 & -0.15 & -2.30 \\
\hline & $300-500$ & 2.12 & & -0.50 & \\
\hline \multirow{5}{*}{ PS78-75 } & $0-50$ & -2.94 & & -4.14 & \\
\hline & $50-100$ & 1.36 & -2.72 & -0.79 & -4.00 \\
\hline & 100-200 & 0.93 & & -0.69 & \\
\hline & $200-300$ & 0.56 & & -1.38 & \\
\hline & $300-500$ & & & & \\
\hline \multirow{5}{*}{ PS78-87 } & $0-50$ & -1.54 & & -2.14 & \\
\hline & $50-100$ & 1.87 & 0.25 & -0.43 & -3.54 \\
\hline & $100-200$ & 1.89 & 0.25 & -1.37 & -2.22 \\
\hline & $200-300$ & 0.23 & & -1.88 & \\
\hline & $300-500$ & -2.56 & & -4.38 & \\
\hline \multirow{5}{*}{ PS78-127 } & $0-50$ & 1.07 & -5.01 & -2.59 & -7.79 \\
\hline & $50-100$ & 2.80 & 1.99 & -0.48 & -1.72 \\
\hline & $100-200$ & 2.06 & 2.39 & -0.98 & -1.51 \\
\hline & $200-300$ & 2.08 & 2.42 & -1.02 & -1.54 \\
\hline & $300-500$ & 2.16 & 1.90 & -1.06 & -1.76 \\
\hline
\end{tabular}


quinqueloba, respectively. Plankton tows from various hydrographic regimes in the Nordic Seas revealed vital offsets of -1.0 and $-1.1 \%$ for $N$. pachyderma and T. quinqueloba, respectively (Simstich et al., 2003). Significantly smaller offsets were reported from the western subpolar North Atlantic, calculated from shells collected with sediment traps (Jonkers et al., 2013). Even studies conducted in the Fram Strait reveal slightly different values (see Stangeew, 2001; Volkmann and Mensch, 2001). Figure 10 comprises results on $\delta^{18} \mathrm{O}_{\text {N.p. }}$ and equilibrium calcite values in the upper water column reported from the Fram Strait.

In our study T. quinqueloba shows larger offsets between the equilibrium calcite values and the measured $\delta^{18} \mathrm{O}$ values than $N$. pachyderma (on average -3.7 and $-1.5 \%$, respectively). Earlier works (e.g. Fairbanks et al., 1980; Lončaric et al., 2006) also recorded a larger negative offset in spinose species compared to nonspinose species. Moreover, symbiont-bearing species, like T. quinqueloba, are known to be more depleted in ${ }^{18} \mathrm{O}$ as a consequence of higher $\mathrm{CO}_{2}$ fixation caused by photosynthesis (Bijma et al., 1990; Spero et al., 1997). In N. pachyderma we found a clear east-west difference in the magnitude of the vital effect along the transect, similar to observations by Volkmann and Mensch (2001). In their study the eastern and western part of the strait yielded significantly different offsets, with highest deviations from the equilibrium calcite values in the west. They concluded that ice coverage increases the magnitude of the vital effect. In our samples in $N$. pachyderma the strongest disequilibrium was indeed found at the two ice-covered stations $(-4.0$ and $-1.8 \%$, at 4 and $5^{\circ} \mathrm{W}$, respectively) and at station 87 $\left(-3.9 \%\right.$ o, at $\left.4^{\circ} \mathrm{E}\right)$. These results are also in line with observations of Bauch et al. (1997) who found slightly increasing isotopic differences between water and plankton samples with decreasing salinity and temperature. Similar to these results, Volkmann and Mensch (2001) observed greater vital offset in the cold and less saline waters of the western Fram Strait. They concluded that unfavourable conditions here make the individuals grow faster (i.e. increase their calcification rate). An increased calcification rate decreases the $\delta^{18} \mathrm{O}$ of tests (McConnaughey, 1989) and may thus increase the disequilibrium. While this hypothesis can explain high offsets at increased calcification rates, the validity of the hypothesis seems rather unlikely as unfavourable conditions generally lead to lower metabolism and thus, decreased calcification rates. Moreover, lower temperatures decrease metabolic rates in all organisms (Hemmingsen, 1960; Gillooly et al., 2001). The abrupt increase in the offset close to the sea-ice margin may rather be explained by increased primary production, associated with the ice margin where ice melting increases stratification and consequently the stability of the water column, which triggers phytoplankton blooms (see Alexander, 1980; Carstens et al., 1997; Pados and Spielhagen, 2014). During biological production dissolved inorganic carbon is consumed. This considerably increases $\mathrm{pH}$ and consequently the carbonate ion concentration
( $\left.\left[\mathrm{CO}_{3}^{2-}\right]\right)$ of the water (Chierchi and Franson, 2009). Spero et al. (1997) showed that increasing seawater $\left[\mathrm{CO}_{3}^{2-}\right]$ decreases the ${ }^{18} \mathrm{O} /{ }^{16} \mathrm{O}$ ratios of the shells of foraminifera and may thus simultaneously increase the vital effect. Still, the effect of carbonate ion concentrations alone cannot explain the high deviation from equilibrium calcite found at the station at $4^{\circ} \mathrm{E}$ where no increased primary production is expected. A possible reason for the increased vital effect at the stations at $5^{\circ} \mathrm{W}, 4^{\circ} \mathrm{W}$ and $4^{\circ} \mathrm{E}$ might also be a sampling during different ontogenetic stages. $N$. pachyderma is known to reproduce on a synodic lunar cycle (Bijma et al., 1990; Schiebel and Hemleben, 2005) and as these three stations were sampled in sequence in the second half of the cruise, it is possible that in the respective samples there were more specimens in early life stages compared to the stations sampled 7-10 days before. Early ontogenetic stages are associated with higher respiration and calcification rates (Hemleben et al., 1989). Rapidly growing skeletons tend to show depletion in both ${ }^{13} \mathrm{C}$ and ${ }^{18} \mathrm{O}$ (McConnaughey, 1989), which could account for the increased vital effect observed at the respective stations.

In contrast to $N$. pachyderma, the offsets found between equilibrium calcite values and the $\delta^{18} \mathrm{O}$ values of $T$. quinqueloba do not follow a clear trend along the transect and show great scatter (Fig. 9). However, the low numbers of specimens found in the samples at most of the stations did not allow us to determine $\delta^{18} \mathrm{O}$ over the whole water column sampled. Moreover, as a consequence, lower numbers of tests (on average ten) were used for stable isotope analysis than in $N$. pachyderma (25), which might also account for the scatter in both $\delta^{13} \mathrm{C}$ and $\delta^{18} \mathrm{O}$ values in T. quinqueloba. We therefore refrain from discussing the vital effect in T. quinqueloba.

Our analysis shows that recent specimens of planktic foraminifera from the water column have a lower oxygen isotopic value than fossils on the sediment surface (Figs. 5, 9). This is in agreement with a number of studies conducted in different regions of the world (e.g. Duplessy et al., 1981; Schmidt and Mulitza, 2002). Berger (1970) suggested in his hypothesis on intraspecific selective dissolution that within one species preferentially the thin-shelled individuals are dissolved during deposition. These tests are secreted during the warmest period of the year and thus, their dissolution increases the average $\delta^{18} \mathrm{O}$ value of the species in the coretop samples. Even though the length of growing season of planktic foraminifera in the Fram Strait is unknown, it has been shown that in the Nordic Seas the production maximum of planktic foraminifera occurs during summer (Kohfeld et al., 1996; Jonkers et al., 2010), with almost zero production during other seasons. This means that the majority of the specimens calcifies the shells under similar conditions. Accordingly, differences in the thickness of tests are not to be expected. Therefore the hypothesis of Berger (1970) cannot explain the isotopic differences between plankton and sediment surface samples in our study area. Lateral transport of 
a
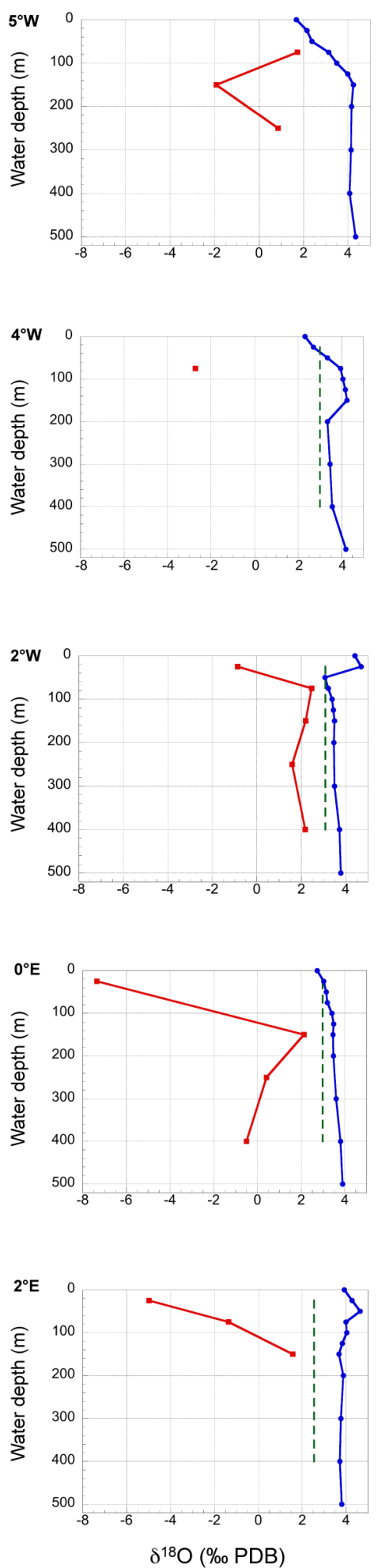

b
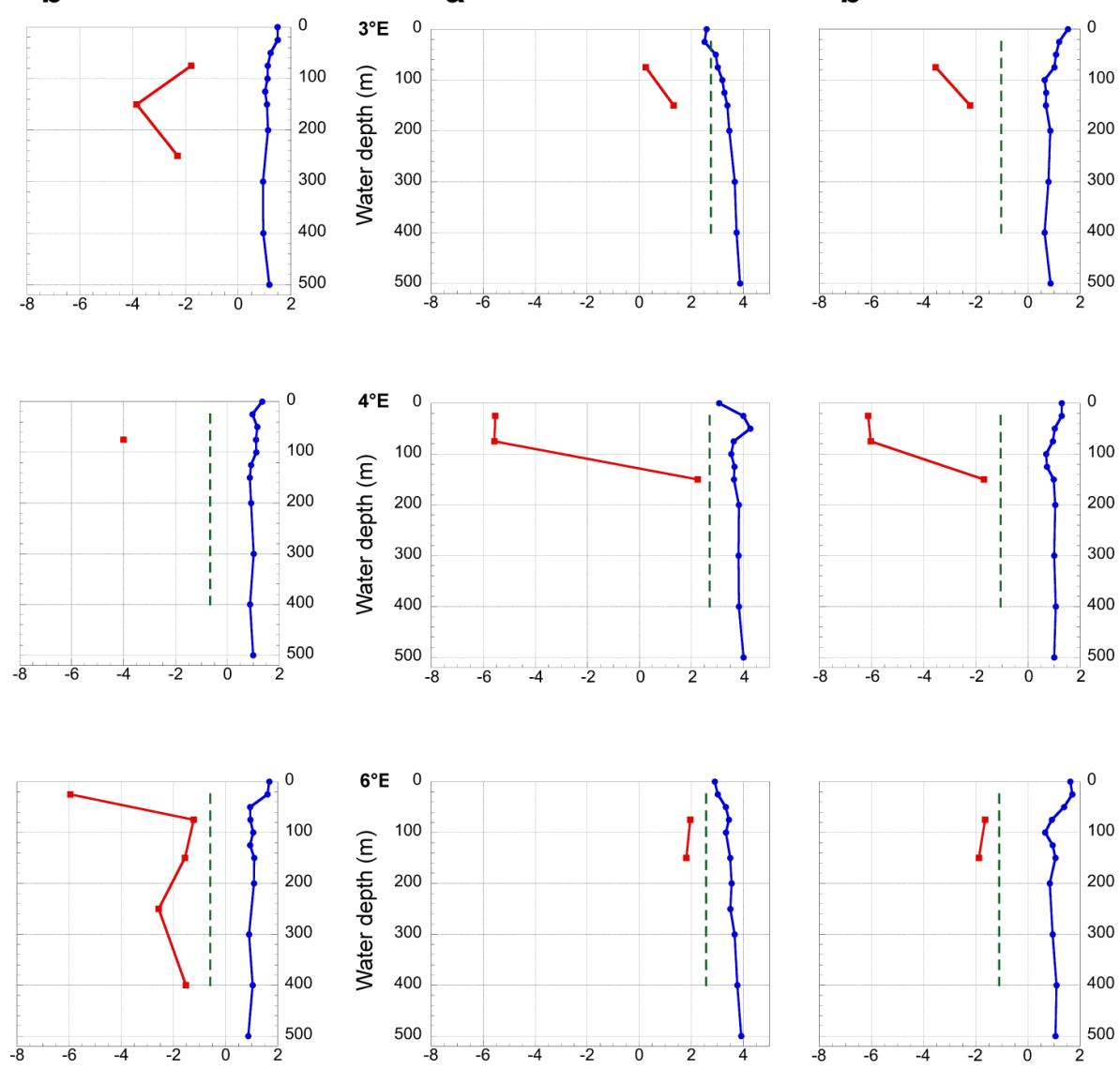

b
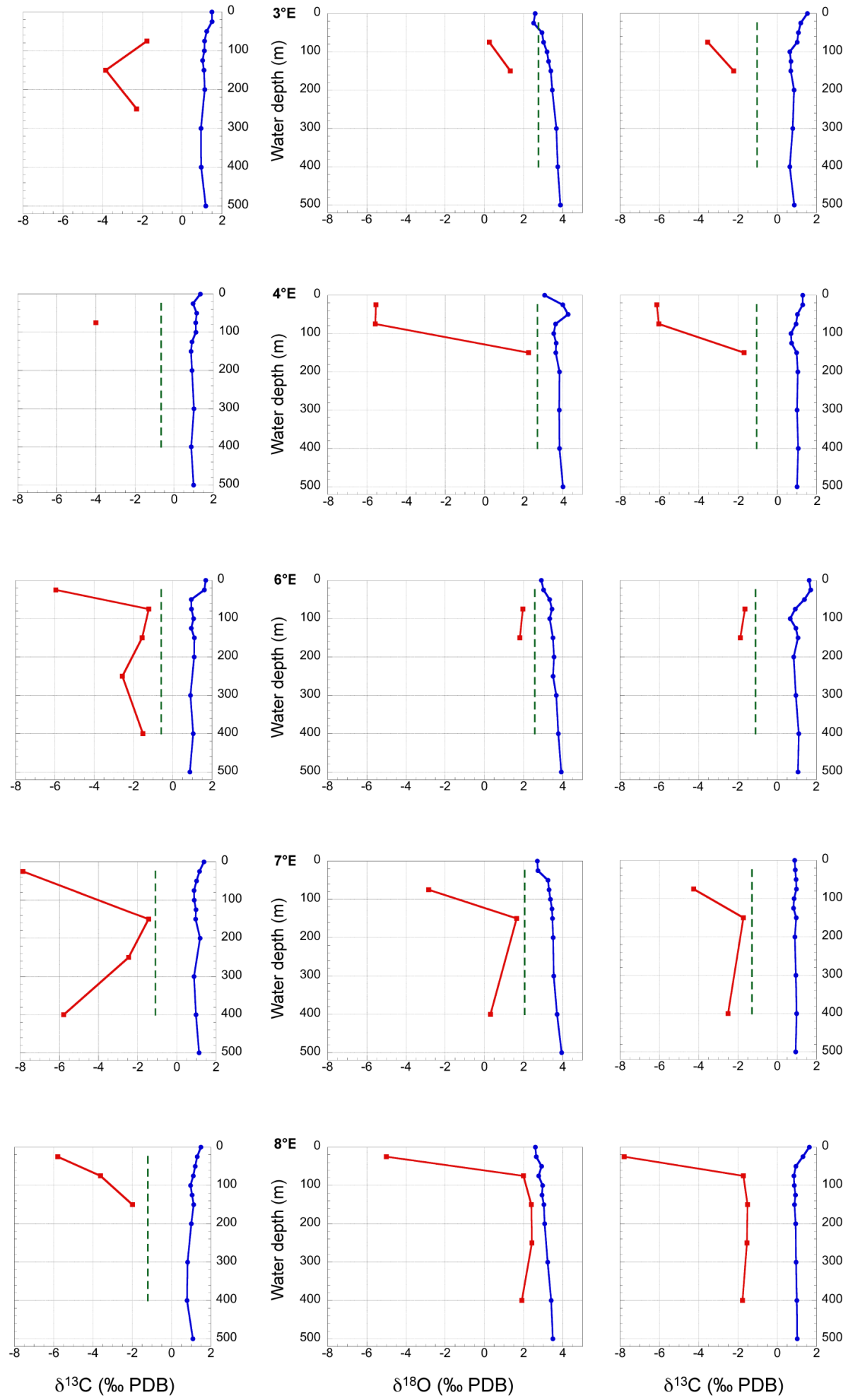

Figure 9. (a) $\delta^{18} \mathrm{O}$ and (b) $\delta^{13} \mathrm{C}$ values of T. quinqueloba from the water column (red squares) and from the sediment surface (green dashed line). The blue dots indicate (a) the equilibrium calcite and (b) the $\delta^{13} \mathrm{C}_{\text {DIC }}$ profile of the water column. 


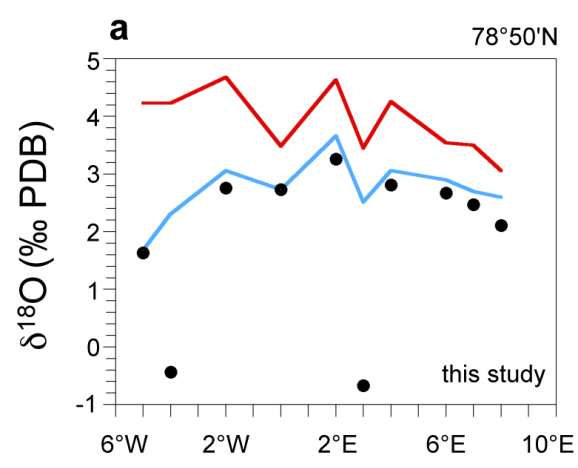

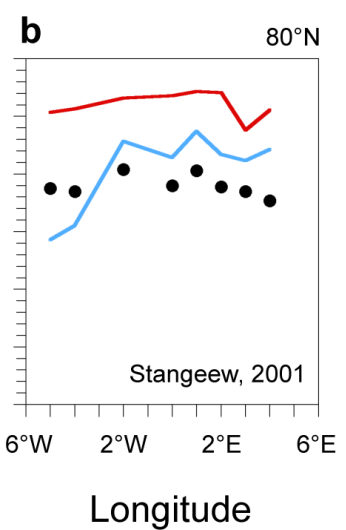

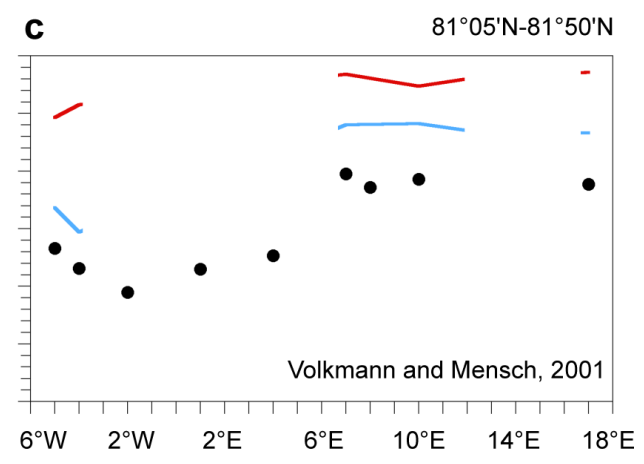

Figure 10. $\delta^{18} \mathrm{O}$ of $N$. pachyderma from the water column (weighted average; black dots) with the range of equilibrium calcite values in the upper $200 \mathrm{~m}$ (blue line: minimum, red line: maximum) along three parallel E-W transects between $78^{\circ} 50^{\prime}$ and $81^{\circ} 50^{\prime} \mathrm{N}$ in the Fram Strait: (a) this study, (b) Stangeew, 2001; Bauch (unpublished data), (c) Volkmann and Mensch, 2001.

the shells during deposition is another effect that could explain the discrepancies. However, mean transport distances in the Fram Strait are only $25-50 \mathrm{~km}$ for $N$. pachyderma and $50-100 \mathrm{~km}$ for T. quinqueloba (von Gyldenfeldt et al., 2000). Even if we consider that specimens may also be carried a similar range during their lifespan, these distances appear too short to transport isotopic signatures from water masses with significantly different temperature/salinity signatures into the sediments. The offset found in the $\delta^{18} \mathrm{O}$ values between plankton and sediment surface samples can be rather attributed to the age difference between living plankton and sediment surface samples. Core top samples are assumed to represent modern conditions in palaeoceanographic reconstructions. Nevertheless, depending on sedimentation rates and bioturbation intensity, their average age can vary in a great range (in the Fram Strait a few decades to $3 \mathrm{ky}$, on average $1 \mathrm{ky}$; see Simstich et al., 2003) while net-sampled foraminifera reflect a snapshot of actual modern conditions. Discrepancies found between isotopic composition of shells collected on the sediment surface and in the water column may therefore be related to changes in the oceanographic parameters between the early summer of 2011 and average conditions during the period represented by sediment surface samples. To explain the lower modern $\delta^{18} \mathrm{O}$ values, the water mass in the calcification depth interval of the foraminifera must have become warmer and/or the $\delta^{18} \mathrm{O}_{\text {water }}$ must have decreased and thus, the salinity signature must have changed significantly. It has been shown indeed that due to increasing river discharges in the last 8 decades (e.g. Peterson et al., 2002) the freshwater budget of the Arctic Ocean has significantly changed (Morison et al., 2012), which resulted in increased freshwater export through the Fram Strait. Moreover, rising temperatures have been documented for the last decades in the Arctic as well (e.g. Zhang et al., 1998; Serreze et al., 2000; Spielhagen et al., 2011). The mean offset found between the $\delta^{18} \mathrm{O}$ values of net-sampled foraminifera and the tests from the sediment surface along the transect is $\sim 1.3 \%$.
Assuming that the oxygen isotope composition of the water remained constant over the time, this difference would correspond to a change in water temperature of about $5^{\circ} \mathrm{C}$. Neglecting the two extremely high offsets found at $4^{\circ} \mathrm{W}$ and $3^{\circ} \mathrm{E}$, the mean offset would decrease to $\sim 0.6 \%$, corresponding to a temperature change of $\sim 2.4^{\circ} \mathrm{C}$. A temperature change of $2.4^{\circ} \mathrm{C}$ is similar to the reconstructed temperature increase of Atlantic Water during the last 200 years (Spielhagen et al., 2011). However, a temperature change of $5^{\circ} \mathrm{C}$ during the last millenium over the whole Fram Strait area seems much too large and, clearly, water temperature changes may not solely account for the differences found in the isotopic composition between modern and fossil foraminifera. The results nevertheless suggest the combined effect of temperature rise and $\delta^{18} \mathrm{O}_{\text {water-change, possible dissolution and }}$ transport effects during the last $\sim 1000$ years.

\subsection{Calcification depth}

With currently available methods we cannot directly determine the actual calcification depth of planktic foraminifera in the water column. Therefore we assume that planktic foraminifera build their shells at the depth where they are most abundant. The average depth of calcification (calculated from the standing stock) of $N$. pachyderma in the Fram Strait lies between $70-150 \mathrm{~m}$ water depth. T. quinqueloba shows a similar calcification range at 50-120 m water depth (Figs. 6 and 7). Both species show deepest average calcification depth at the easternmost station. Our results are in accordance with Simstich et al. (2003) who calculated an apparent calcification depth for $N$. pachyderma of 70-130 m and 70$250 \mathrm{~m}$ in the EGC and off Norway, respectively. From the Nansen Basin (eastern Arctic Ocean), Bauch et al. (1997) reported a deeper average calcification depth for N. pachyderma. However, in the northern regime of the Nansen Basin, where the water column properties are similar to those in the western Fram Strait, N. pachyderma prefers shallower wa- 
ters than in the southern Nansen Basin where the water column is strongly influenced by the subsurface inflow of Atlantic Waters (Bauch et al., 1997). This trend observed by Bauch et al. (1997) coincides with our results. The difference found in calcification depths in the Nansen Basin and in the Fram Strait might be caused by the different habitats that these locations represent. The northern Nansen Basin is covered by sea ice throughout the year and thus represents a different habitat for planktic foraminifera than the narrow Fram Strait. Here, the interannual E-W variability in the position of the average summer sea-ice margin is high and the ice-covered stations sampled in this study might therefore be ice-free in another summer. It has been shown that the depth habitat of planktic foraminifera in the Fram Strait in the early summer is predominantly controlled by the position of the deep chlorophyll maximum (Pados and Spielhagen, 2014). The permanent ice cover in the Nansen Basin may alter the factors controlling the depth habitat of foraminifera and may consequently cause a different depth habitat (and calcification depth) than in the Fram Strait.

Calculating the vital effect from differences between water and plankton samples at each depth level assumes that foraminifera calcified their tests at the depth interval where they were caught. This might not be true, as foraminifera are known to migrate in the water column during their life cycle. Alternatively we may assume that the main encrustation process of foraminifera indeed happened solely at the average calcification depth that is derived in our study from the standing stock. When calculating the average offset between water and foraminifera for the calcification depth only, a vital effect of $-0.9 \pm 0.5 \%$ in $N$. pachyderma and $-3.1 \pm 2.9 \%$ o in T. quinqueloba is determined. These vital effects are significantly smaller than those determined over the whole water column, which are $-1.5 \pm 1.3 \%$ and $-3.7 \pm 1.7 \%$ for N. pachyderma and T. quinqueloba, respectively. In general, we have to take into account that both calcification-scenarios represent extreme cases and the actual vital effect may be between these two extremes.

\subsection{Carbon isotope values of DIC and foraminifera}

The interpretation of the carbon isotope composition of foraminiferal shells is quite complicated as several factors can influence the carbon isotope incorporation. The gas exchange between sea and atmosphere, the biological production, the community respiration and species-dependent incorporations of carbon isotopes are the main processes that can affect the ${ }^{13} \mathrm{C} /{ }^{12} \mathrm{C}$ ratio in calcite tests. A number of studies reported on a consistent offset between $\delta^{13} \mathrm{C}$ of calcite shells and the $\delta^{13} \mathrm{C}_{\text {DIC }}$ measured within the water column (e.g. Bauch et al., 2000; Volkmann and Mensch, 2001). According to Romanek et al. (1992) the $\delta^{13} \mathrm{C}$ of inorganic calcite that precipitates in equilibrium with seawater is $1 \%$ o higher

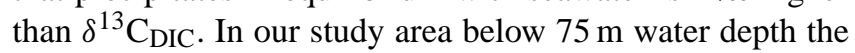
$\delta^{13} \mathrm{C}$ values of $N$. pachyderma run relatively parallel to the $\delta^{13} \mathrm{C}_{\text {DIC }}$, but with an average offset of $-1.6 \pm 0.7 \%$. This reveals a vital effect of about $-2.6 \%$. Kohfeld et al. (1996) reported from the Northeast Water Polynya on the Greenland shelf a vital effect of $-1 \%$ while another study in the Nansen Basin (Bauch et al., 2000) revealed a vital effect of $-2 \%$. The discrepancies found here may suggest the influence of oceanographic variability on the vital effect in $\delta^{13} \mathrm{C}$ of $N$. pachyderma. The $\delta^{13} \mathrm{C}$ of $T$. quinqueloba shows a stronger vertical scatter with an average vital effect of $-4.6 \pm 1.5 \%$. Again we emphasize that in the case of T. quinqueloba the low amounts of calcite analysed might have also influenced the results. Nevertheless, in the upper 75-100 $\mathrm{m}$ of the water column for both species the $\delta^{13} \mathrm{C}_{\mathrm{DIC}}$ and the $\delta^{13} \mathrm{C}$ of shells show an exactly reverse tendency (Figs. 5, 9): the $\delta^{13} \mathrm{C}_{\text {DIC }}$ is increasing towards sea surface while the $\delta^{13} \mathrm{C}$ of the tests is decreasing. The high $\delta^{13} \mathrm{C}_{\text {DIC }}$ values found close to the sea surface are assumed to be caused by high primary production, resulting in enrichment in ${ }^{13} \mathrm{C}$ (Fogel and Cifuentes, 1993): as ${ }^{12} \mathrm{C}$ is taken for photosynthesis, the water becomes enriched in ${ }^{13} \mathrm{C}$. However, if no other processes would affect the incorporation of carbon into the calcite shells, the tests should also show the enrichment in ${ }^{13} \mathrm{C}$. One possible explanation for the deviation in the upper $\sim 75 \mathrm{~m}$ could be the effect of high (near-surface) temperatures on the carbon isotope incorporation of the tests. Laboratory (Bemis et al., 2000) and field experiments (Jonkers et al., 2013) have shown that foraminiferal $\delta^{13} \mathrm{C}$ linearly decreases with increasing temperatures. However, in our data set the offsets measured between $\delta^{13} \mathrm{C}_{\mathrm{DIC}}$ and $\delta^{13} \mathrm{C}_{\text {foraminifera have no cor- }}$ relation with in situ water temperatures. Therefore this hypothesis cannot explain in our case the greater vital effect found in near-surface waters.

Another explanation for the deviation might be an increased carbonate ion concentration $\left(\left[\mathrm{CO}_{3}^{2-}\right]\right)$ as a consequence of strong biological production in the upper water column (Chierchi and Franson, 2009). Both culturing (Spero et al., 1997) and field experiments (Bauch et al., 2002) have shown that the carbon isotope composition of foraminifera is correlated to the carbonate ion concentration of the water. The "carbonate ion effect" (CIE) describes that increasing seawater $\left[\mathrm{CO}_{3}^{2-}\right]$ causes depletion in ${ }^{13} \mathrm{C}$ of the foraminiferal tests. The CIE could therefore explain our observed low $\delta^{13} \mathrm{C}$ values of shells living in ${ }^{13} \mathrm{C}$ enriched waters. A direct interpretation of this effect is not possible as during cruise ARK-XXVI/1 the concentration of $\left[\mathrm{CO}_{3}^{2-}\right]$ or the parameters needed to calculate $\left[\mathrm{CO}_{3}^{2-}\right]$ (e.g. $\mathrm{pH}$ and total alkalinity of the water samples) were not determined. However, vertical profiles of $\left[\mathrm{CO}_{3}^{2-}\right]$ measured in the area (CARINA database, 2015) show in the upper $500 \mathrm{~m}$ of the water column a quite uniform $\left[\mathrm{CO}_{3}^{2-}\right]$ distribution, with values of $100-120 \mu \mathrm{mol} \mathrm{kg} \mathrm{kg}^{-1}$. Only at the surface in the WSC (upper $50 \mathrm{~m}$ ) values are higher (up to $\left.160 \mu \mathrm{mol} \mathrm{kg}{ }^{-1}\right)$. Applying the observed effect on Globigerina bulloides $\left(-1.3 \%\right.$ in $\delta^{13} \mathrm{C}_{\text {foraminifera }} / 100 \mu \mathrm{mol} \mathrm{kg}^{-1}$ in 
$\left[\mathrm{CO}_{3}^{2-}\right]$; Spero et al., 1997) the range of about $50 \mu \mathrm{mol} \mathrm{kg}-1$ in $\left[\mathrm{CO}_{3}^{2-}\right]$ implies a potential effect of $-0.65 \%$ on the $\delta^{13} \mathrm{C}$ values of foraminifera, and thus might explain the lower values found in the surface waters in the east. However, we cannot see this difference between east and west in the offsets measured between $\delta^{13} \mathrm{C}_{\mathrm{DIC}}$ and $\delta^{13} \mathrm{C}_{\mathrm{N} \text {.p. }}$, which points to the fact that other processes are responsible for the deviation found in near-surface waters as well. Nevertheless, assuming that the vital effect in $\delta^{13} \mathrm{C}$ close to the sea surface is influenced by increased carbonate ion concentrations induced through high primary production, the smaller average vital effects reported by Volkmann and Mensch (2001; $-2.15 \%$ ) and Stangeew $(2001 ;-2 \%$ ) from the Fram Strait more than 10 years earlier may point to an increase in bioproductivity during the last decades in the area. Data sets of $\left[\mathrm{CO}_{3}^{2-}\right]$ recorded between 1982 and 2002 in the Fram Strait (CARINA database, 2015) however do not show respective changes, which may indicate a significant shift only after 2002. We also have to consider that bioproductivity may vary interannually and within the summer season.

As also discussed with respect to the offset in $\delta^{18} \mathrm{O}$ between coretop and living foraminifera, the age of sediment surface samples can vary in a great range (between modern to $3 \mathrm{ky}$, with an average of $\sim 1 \mathrm{ky}$; Simstich et al., 2003). Accordingly, they may reflect significantly older environments than the plankton samples. The negative offset in $\delta^{13} \mathrm{C}$ between the sediment and plankton samples may thus be explained by the surface ocean Suess effect: during the last 100 years the carbon isotope composition of the atmosphere has changed due to the increased anthropogenic combustion of fossil carbon which is extremely negative in $\delta^{13} \mathrm{C}$. The $\delta^{13} \mathrm{C}$ values of the atmospheric $\mathrm{CO}_{2}$ have decreased by about $1.4 \%$ (Friedli et al., 1986; Francey et al., 1999) and the concurrent shift in the stable carbon isotope composition of ocean surface water is reflected in the decrease of $\delta^{13} \mathrm{C}$ of recent foraminiferal shells (Bauch et al., 2000). The offset of roughly $-1 \%$ in $\delta^{13} \mathrm{C}$ between the sediment and plankton samples observed both in this study and in that of Bauch et al. (2000) may therefore be explained by the different ages of the carbonate in both sample sets and the developments that have occurred in the last ca. 100 years.

\section{Conclusions}

1. The polar species Neogloboquadrina pachyderma clearly dominates the foraminiferal species assemblage in the Fram Strait in the early summer. Subpolar Turborotalita quinqueloba accounts for only 5-23\%.

2. In the study area both species dwell shallower under the ice cover than in the open ocean. The average depth of calcification of $N$. pachyderma lies between 70-150 m water depth, T. quinqueloba shows a similar range with 50-120 m water depth.
3. When calculating the average vital effect in the oxygen isotope composition for the whole sampled water column, $N$. pachyderma and T. quinqueloba show an average offset of about -1.5 and $-3.7 \%$ (respectively) compared to calculated equilibrium calcite values. These vital effects are higher than those determined at the calcification depth only where they are $-0.9 \%$ o for N. pachyderma and $-3.1 \%$ for T. quinqueloba.

4. The $\delta^{13} \mathrm{C}_{\mathrm{DIC}}$ and the $\delta^{13} \mathrm{C}$ values of the net-sampled shells show an average offset of -1.6 and $-3.6 \%$ for $N$. pachyderma and T. quinqueloba, respectively. The discrepancies with earlier published results may suggest the influence of regional variability on the vital effect in $\delta^{13} \mathrm{C}$.

5. In the upper $\sim 75 \mathrm{~m}$ of the water column the $\delta^{13} \mathrm{C}_{\mathrm{DIC}}$ and the $\delta^{13} \mathrm{C}$ of shells of both species show an exactly reverse tendency that might relate to the influence of the "carbonate ion effect" on the carbon isotope incorporation in the tests.

6. The shells of both species collected from the water column yield lower $\delta^{18} \mathrm{O}$ and $\delta^{13} \mathrm{C}$ values than those from the sediment surface, suggesting a significant change of the stable isotope ratios in the recent past (last centuries, likely the last 100-150 years only) The negative offset in $\delta^{18} \mathrm{O}$ between the sediment and plankton samples suggests a combined effect of temperature rise and

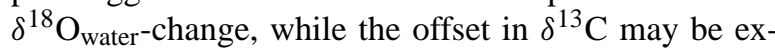
plained by the surface ocean Suess effect.

Acknowledgements. The authors wish to thank the captain and crew of RV Polarstern and the Alfred Wegener Institute, Helmholtz Centre for Polar and Marine Research in Bremerhaven for support during the cruise ARK-XXVI/1. We are indebted to Angelina Kraft for assisting in the deployments of the MultiNet sampler and to Maciej Telesinski for collecting the sediment surface samples for this study. Agnieszka Beszczynska-Möller and Andreas Wisotzki provided the CTD data for the study. Thanks also go to Hartmut Schulz for kindly providing the low temperature vacuum asher at the University of Tübingen and for his hospitality and technical assistance during the process. Lukas Jonkers and two anonymous reviewers gave important comments that significantly helped to improve the manuscript. This research was conducted with funding of the European Community's 7th Framework Programme FP7 2007/2013, Marie-Curie Actions, under Grant Agreement No. 238111 - CASE ITN. R. F. Spielhagen acknowledges the financial support through the "Akademienprogramm" by the Academy of Sciences, Humanities, and Literature Mainz.

Edited by: A. Shemesh 


\section{References}

Alexander, V.: Interrelationships between the seasonal sea ice and biological regimes, Cold Reg. Sci. Technol., 2, 157-178, 1980.

Bauch, D., Carsens, J., and Wefer, G.: Oxygen isotope composition of living Neogloboquadrina pachyderma (sin.) in the Arctic Ocean, Earth Planet. Sc. Lett., 146, 47-58, 1997.

Bauch, D., Carstens, J., Wefer, G., and Thiede, J.: The imprint of anthropogenic $\mathrm{CO}_{2}$ in the Arctic Ocean: evidence from planktic $\delta^{13} \mathrm{C}$ data from water column and sediment surfaces, Deep-Sea Res. Pt. II., 47, 1791-1808, 2000.

Bauch, D., Erlenkeuser, H., Winckler, G., Pavlova, G., and Thiede, J.: Carbon isotopes and habitat of polar planktic foraminifera in the Okhotsk Sea: the 'carbonate ion effect' under natural conditions, Mar. Micropaleontol., 45, 83-99, 2002.

Bemis, B. E., Spero, H. J., Bijma, J., and Lea, D. W.: Reevaluation of the oxygen isotopic composition of planktonic foraminifera: Experimental results and revised paleotemperature equations, Paleoceanography, 13, 150-160, 1998.

Bemis, B. E., Spero, H. J., Lea, D. W., and Bijma, J.: Temperature influence on the carbon isotopic composition of Globigerina bulloides and Orbulina universa (planktonic foraminifera), Mar. Micropaleontol., 38, 213-228, 2000.

Berberich, D.: Die planktische Foraminifere Neogloboquadrina pachyderma (Ehrenberg) im Weddellmeer, Antarktis [The planktonic foraminifera Neogloboquadrina pachyderma (Ehrenberg) in the Weddell Sea, Antarctica], Berichte zur Polarforschung (Reports on Polar Research), 195, 1-193, 1996.

Berger, W. H.: Planktonic foraminifera: selective solution and the lysocline, Mar. Geol., 8, 111-138, 1970.

Beszczynska-Möller, A. and Wisotzki, A.: Physical oceanography during POLARSTERN cruise ARKXXVI/1, Alfred Wegener Institute, Helmholtz Centre for Polar and Marine Research, Bremerhaven, doi:10.1594/PANGEA.774196, 2012.

Beszczynska-Möller, A., Woodgate, R. A., Lee, C., Melling, H., and Karcher, M.: A synthesis of exchanges through the main oceanic gateways to the Arctic Ocean. In: The Changing Arctic Ocean: Special Issue on the International Polar Year (20072009), Oceanography, 24, 82-99, 2011.

Bijma, J., Erez, J., and Hemleben, C.: Lunar and semi-lunar reproductive cycles in some spinose planktonic foraminifers, J. Foramin. Res., 20, 117-127, 1990.

CARbon dioxide IN the Atlantic Ocean: http://cdiac.ornl.gov/ oceans/CARINA/, last access: 12 January 2015.

Carstens, J., Hebbeln, D., and Wefer, G.: Distribution of planktic foraminifera at the ice margin in the Arctic (Fram Strait), Mar. Micropaleontol., 29, 257-269, 1997.

Chierici, M. and Fransson, A.: Calcium carbonate saturation in the surface water of the Arctic Ocean: undersaturation in freshwater influenced shelves, Biogeosciences, 6, 2421-2431, doi:10.5194/bg-6-2421-2009, 2009.

Darling, K. F., Kucera, M., Kroon, D. and Wade, C. M.: A resolution for the coiling direction paradox in Neogloboquadrina pachyderma, Paleoceanography, 21, PA2011, doi:10.1029/2005PA001189, 2006.

Dickson, R. R., Osborn, T. J., Hurrell, J. W., Meincke, J., Blindheim, J., Adlandsvik, B., Vinje, T., Alekseev, G. and Maslowski, W.: The Arctic Ocean response to the North Atlantic Oscillation, J. Climate, 13, 2671-2696, 2000.

Duplessy, J. C.: Isotope studies, Climatic Change, 3, 47-67, 1978.
Duplessy, J. C., Bé, A. W. H., and Blanc, P. L.: Oxygen and carbon isotopic composition and biogeographic distribution of planktonic foraminifera in the Indian Ocean, Palaeogeogr. Palaeoclimatol. Palaeoecol., 33, 9-46, 1981.

Duplessy, J. C., Labeyrie, L., Arnold, M., Paterne, M., Duprat, J., and van Weering, T. C.: Changes in surface salinity of the North Atlantic Ocean during the last deglaciation, Nature, 358, 485488, 1992.

Ehrenberg, C. G.: Über die Tiefgrund-Verhältnisse des Oceans am Eingange der Davisstrasse und bei Island (About sea bottom conditions at the mouth of Davis Strait and near Iceland), Monatsbericht der Königlichen Preussischen Akademie der Wissenschaften zu Berlin 1861, 275-315, 1861.

Erez, J. and Luz, B.: Experimental paleotemperature equation for planktonic foraminifera, Geochim. Cosmochim. Acta, 47, 10251031, 1983.

Fairbanks, R. G., Wiebe, P. H., and Be, A. W. H.: Vertical distribution and isotopic composition of living planktonic foraminifera in the western North Atlantic, Science, 207, 61-63, 1980.

Fogel, M. L. and Cifuentes, L. A.: Isotope fractionation during primary production, in: Organic geochemistry, Springer US, 73-98, 1993.

Francey, R. J., Allison, C. E., Etheridge, D. M., Trudinger, C. M., Enting, I. G., Leuenberger, M., Langenfelds, R. L., Michel, E., and Steele, L. P.: A 1000-year high precision record of $\delta^{13} \mathrm{C}$ in atmospheric $\mathrm{CO}_{2}$, Tellus B, 51, 170-193, 1999.

Friedli, H., Lötscher, H., Oeschger, H., Siegenthaler, U., and Stauffer, $\mathrm{B}$.: Ice core record of the ${ }^{13} \mathrm{C} /{ }^{12} \mathrm{C}$ ratio of atmospheric $\mathrm{CO}_{2}$ in the past two centuries, Nature, 324, 237-238, 1986.

Gillooly, J. F., Brown, J. H., West, G. B., Savage, V. M., and Charnov, E. L.: Effects of size and temperature on metabolic rate, Science, 293, 2248-2251, 2001.

Hecht, A. D.: An ecologic model for test size variation in recent planktonic foraminifera; applications to the fossil record, J. Foramin. Res., 6, 295-311, 1976.

Hemleben, C., Spindler, M., and Anderson, O. R.: Modern planktonic foraminifera, Springer, New York, 1989.

Hemmingsen, A. M.: Energy metabolism as related to body size and respiratory surfaces, and its evolution. Rep. Steno Mem. Hosp. Nord. Insulinlab., 9, 1-110, 1960.

Jakobsson, M., Mayer, L., Coakley, B., Dowdeswell, J. A., Forbes, S., Fridman, B., Hodnesdal, H., Noormets, R., Pedersen, R., Rebesco, M., Schenke, H. W., Zarayskaya, Y., Accettella, D., Armstrong, A., Anderson, R. M., Bienhoff, P., Camerlenghi, A., Church, I., Edwards, M., Gardner, J. V., Hall, J. K., Hell, B., Hestvik, O., Kristoffersen, Y., Marcussen, C., Mohammad, R., Mosher, D., Nghiem, S. V., Pedrosa, M. T., Travaglini, P. G., and Weatherall, P.: The International Bathymetric Chart of the Arctic Ocean (IBCAO) version 3.0., Geophys. Res. Lett., 39, L12609, doi:10.1029/2012GL052219, 2012.

Johanessen, O. M.: Brief overview of the physical oceanography, in: The Nordic Seas, edited by: Hurdle, B. G., Springer, New York, 103-128, 1986.

Jones, E. P.: Circulation in the Arctic Ocean, Polar Res., 20, 139146, 2001.

Jonkers, L., Brummer, G.-J. A., Peeters, F. J. C., van Aken, H. M., and De Jong, M. F.: Seasonal stratification, shell flux, and oxygen isotope dynamics of left-coiling $N$. pachyderma (sin.) and 
T. quinqueloba in the western subpolar North Atlantic, Paleoceanography, 25, PA2204, doi:10.1029/2009PA001849, 2010.

Jonkers, L., Heuven, S., Zahn, R., and Peeters, F. J.: Seasonal patterns of shell flux, $\delta^{18} \mathrm{O}$ and $\delta^{13} \mathrm{C}$ of small and large N. pachyderma $(s)$ and G. bulloides in the subpolar North Atlantic, Paleoceanography, 28, 164-174, 2013.

Kahn, M. I.: Non-equilibrium oxygen and carbon isotopic fractionation in tests of living planktonic-foraminifera, Oceanol. Acta, 2, 195-208, 1979.

Kellogg, T., Duplessy, J. C. and Shackleton, N.: Planktonic foraminiferal and oxygen isotopic stratigraphy and paleoclimatology of Norwegian Sea deep-sea cores, Boreas, 7, 61-73, 1978.

Kohfeld, K. E., Fairbanks, R. G., Smith, S. L., and Walsh, I. D.: Neogloboquadrina pachyderma (sinistral coiling) as paleoceanographic tracers in polar oceans: Evidence from Northeast Water Polynya plankton tows, sediment traps, and surface sediments, Paleoceanography, 11, 679-699, 1996.

Lončaric, N., Peeters, F. J. C., Kroon, D. and Brummer, G.-J. A.: Oxygen isotope ecology of recent planktic foraminifera at the central Walvis Ridge (SE Atlantic), Paleoceanography, 21, PA3009, doi:10.1029/2005PA001207, 2006.

McConnaughey, T.: ${ }^{13} \mathrm{C}$ and ${ }^{18} \mathrm{O}$ isotopic disequilibrium in biological carbonates: I. Patterns, Geochim. Cosmochim. Acta, 53, 151162,1989

Meyer, H., Schoenicke, L., Wand, U., Hubberten, H.-W., and Friedrichsen, H.: Isotope studies of hydrogen and oxygen in ground ice - Experiences with the equilibration technique, Isot. Environ. Healt. S., 36, 133-149, 2000.

Morison, J., Kwok, R., Peralta-Ferriz, C., Alkire, M., Rigor, I., Andersen R., and Steele, M.: Changing Arctic Ocean freshwater pathways, Nature, 481, 66-70, 2012.

Natland, M. L.: New species of foraminifera from off the west coast of North America and from the later Tertiary of the Los Angeles Basin, Scripp. Instit. Oceanogr. Bull. Techn. Ser., 4, 137-164, 1938.

O’Neil, J. R., Clayton, R. N., and Mayeda, T. K.: Oxygen isotope fractionation in divalent metal carbonates, J. Chem. Phys., 51, 5547-58, 1969.

Pados, T. and Spielhagen, R.F.: Species distribution and depth habitat of recent planktic foraminifera in the Fram Strait (Arctic Ocean), Pol. Res., 33, 22483, doi:10.3402/polar.v33.22483, 2014.

Peterson, B. J., Holmes, R. M., McClelland, J. W., Vörösmarty, C. J., Lammers, R. B., Shiklomanov, A. I., and Rahmstorf, S.: Increasing river discharge to the Arctic Ocean, Science, 298, 21712173, 2002.

Romanek, C. S., Grossman, E. L., and Morse, J. W.: Carbon isotopic fractionation in synthetic aragonite and calcite: effects of temperature and precipitation rate, Geochim. Cosmochim. Acta, 56, 419-430, 1992.

Rudels, B., Friedrich, H. J., and Quadfasel, D.: The Arctic Circumpolar Boundary Current, Deep-Sea Res. Pt. II, 46, 1023-1062, 1999.
Rudels, B., Meyer, R., Fahrbach, E., Ivanov, V. V., Østerhus, S., Quadfasel, D., Schauer, U., Tverberg, V., and Woodgate, R. A.: Water mass distribution in Fram Strait and over the Yermak Plateau in summer 1997, Ann. Geophys., 18, 687-705, 2000, http://www.ann-geophys.net/18/687/2000/.

Schiebel, R. and Hemleben, C.: Modern planktic foraminifera. Paläontologische Zeitschrift, 79, 135-148, 2005.

Schmidt, G. A. and Mulitza, S.: Global calibration of ecological models for planktic foraminifera from coretop carbonate oxygen18, Mar. Micropaleontol., 44, 125-140, 2002.

Serreze, M. C., Walsh, J. E., Chapin, III. F. S., Osterkamp, T., Dyurgerov, M., Romanovsky, V., Oechel, W. C., Morison, J., Zhang, T., and Barry, R. G.: Observational evidence of recent change in the northern high latitude environment, Clim. Chang., 46, 159-207, 2000.

Shackleton, N. J., Wiseman, J. D. H., and Buckley, H. A.: Nonequilibrium isotopic fractionation between seawater and planktonic foraminiferal tests, Nature, 242, 177-179, 1973.

Simstich, J., Sarnthein, M., and Erlenkeuser, H.: Paired $\delta^{18} \mathrm{O}$ signals of Neogloboquadrina pachyderma (s) and Turborotalita quinqueloba show thermal stratification structure in the Nordic Seas, Mar. Micropaleontol., 48, 107-125, 2003.

Spero, H. J.: Do planktic foraminifera accurately record shifts in the carbon isotopic composition of seawater $\Sigma \mathrm{CO}_{2}$ ?, Mar. Micropaleontol., 19, 275-285, 1992.

Spero, H. J. and Deniro, M. J.: The influence of symbiont photosynthesis on the $\delta^{18} \mathrm{O}$ and $\delta^{13} \mathrm{C}$ values of planktonic foraminiferal shell calcite, Symbiosis, 4, 213-228, 1987.

Spero, H. J., Bijma, J., Lea, D. W., and Bemis, B. E.: Effect of seawater carbonate concentration on foraminiferal carbon and oxygen isotopes, Nature, 390, 497-500, 1997.

Spielhagen, R. F., Werner, K., Sorensen, S. A., Zamelczyk, K., Kandiano, E., Budeus, G., Husum, K., Marchitto, T. M., and Hald, M.: Enhanced modern heat transfer to the Arctic by warm Atlantic water, Science, 331, 450-453, 2011.

Stangeew, E.: Distribution and isotopic composition of living planktonic foraminifera N. pachyderma (sinistral) and T. quinqueloba in the high latitude North Atlantic, Doctoral dissertation, 2001.

Vergnaud Grazzini, C.: Non-equilibrium isotopic compositions of shells of planktonic foraminifera in the Mediterranean Sea, Paleogeogr. Paleoclimatol. Paleoecol., 20, 263-276, 1976.

Volkmann, R.: Planktic foraminifers in the outer Laptev Sea and the Fram Strait - Modern distribution and ecology, J. Foramin. Res., 30, 157-176, 2000.

Volkmann, R. and Mensch, M.: Stable isotope composition $\left(\delta^{18} \mathrm{O}\right.$, $\delta^{13} \mathrm{C}$ ) of living planktic foraminifers in the outer Laptev Sea and the Fram Strait, Mar. Micropaleontol., 42, 163-188, 2001.

von Gyldenfeldt, A.-B., Carstens, J., and Meincke, J.: Estimation of the catchment area of a sediment trap by means of current meters and foraminiferal tests, Deep-Sea Res. Pt. II, 47, 17011717, 2000.

Zhang, J., Rothrock, D. A., and Steele, M.: Warming of the Arctic Ocean by a strengthened Atlantic inflow: Model results, Geophys. Res. Lett., 25, 1745-1748, 1998. 